\title{
Hodgkin's disease: histological classification and diagnosis
}

\author{
R. M. CROSS \\ From the Royal Air Force Institute of Pathology and Tropical Medicine, Halton, Buckinghamshire
}

SYNOPSIS A review of the previous histological classifications of Hodgkin's disease seems to show that they are insufficiently accurate in regard to prognosis and difficult to apply but a detailed study of a large number of cases suggests that certain criteria allow of subdivision of the disease into types. These criteria are the proportion of mature lymphocytes, the presence of plentiful mature histiocytes, the presence of fibrous nodularity, and the numbers of abnormal reticulum cells and their degree of anaplasia.

Three primary histological subdivisions seem to arise from a study of 302 patients, namely, the reticular, histiocytic, and nodular sclerosis groups. These are further divided into well differentiated and poorly differentiated on the basis of their lymphocyte content and the degree of anaplasia of the abnormal reticulum cells.

The histological appearances of each type are described. The application of this histological classification has been shown to correlate well with the clinical outcome.

In 1832, Thomas Hodgkin described seven patients who had a disease characterized by generalized lymphadenopathy and splenomegaly, to which, in 1865, Wilks gave the name Hodgkin's disease. The aetiology of the disease is as obscure today as it was then.

The terminology associated with Hodgkin's disease is confusing. Greenfield (1878) used the names lymphadenoma and Hodgkin's disease synonymously; the term Hodgkin's 'granuloma' probably arose from Sternberg's (1898) work. Letterer (1924) introduced the term reticulosis to describe any progressive hyperplasia of the reticuloendothelial system; on this basis, Pullinger (1932) referred to Hodgkin's disease as fibromyeloid reticulosis, and Robb-Smith (1938) divided his cases of Hodgkin's disease into lymphoreticular and fibromyeloid forms of medullary reticulosis. Gall and Mallory (1942) introduced a classification of malignant lymphoma in which Hodgkin's disease was divided into Hodgkin's lymphoma and Hodgkin's sarcoma.

\section{CLASSIFICATION OF JACKSON AND PARKER (1944)}

A major step in classification was the work of Jackson and Parker (1944), who divided Hodgkin's disease into early Hodgkin's disease (later called paragranuloma), granuloma, and . sarcoma. This classification has been used for many years and the proportion of these three types of Hodgkin's disease as reported in the literature, is seen in Table $I$. Paragranuloma has long been recognized as having a favourable prognosis and Hodgkin's sarcoma a poor one. These two groups, however, represented less than $20 \%$ of the total number of cases of Hodgkin's disease.

\section{TABLE I}

CLASSIFICATION OF HODGKIN'S DISEASE INTO THREE TYPES BY JACKSON AND PARKER AND DISTRIBUTION OF CASES IN OTHER SERIES

\begin{tabular}{llr} 
Author & Classification & \multicolumn{1}{c}{$\begin{array}{c}\text { No. } \\
\text { of Cases }\end{array}$} \\
\hline Jackson and Parker (1944) & Paragranuloma & $28(10 \%)$ \\
& Granuloma & $136(79 \%)$ \\
Smetana and Cohen (1956) & Sarcoma & $32(11 \%)$ \\
& Paragranuloma & $35(10 \%)$ \\
& Granuloma & $308(89 \%)$ \\
Wright (1956) & Sarcoma & $5(1 \%)$ \\
& Paragranuloma & $19(7 \%)$ \\
Hilton and Sutton (1962) & Granuloma & $157(90 \%)$ \\
& Sarcoma & $10(3 \%)$ \\
& Paragranuloma & $12(5 \%)$ \\
Hanson (1964) & Granuloma & $137(94 \%)$ \\
& Sarcoma & $3(1 \%)$ \\
& Paragranuloma & $22(12 \%)$ \\
Lukes (1963) & Granuloma & $154(84 \%)$ \\
& Sarcoma & $8(4 \%)$ \\
& Paragranuloma & $30(8 \%)$ \\
& Granuloma & $344(91 \%)$ \\
& Sarcoma & $3(1 \%)$
\end{tabular}


The main disadvantage of the classification of Jackson and Parker was that on average $80 \%$ of the cases fell into the 'granuloma' group, and had such varied survival times that there was little prognostic value in the classification. Because of the limitation in the Jackson and Parker classification, there appeared to be some justification for the opinions of Peters (1950) and Aisenberg (1964) that clinical 'staging' of Hodgkin's disease on first presentation of the illness was a more reliable guide to prognosis than histology.

\section{CLASSIFICATION OF LUKES AND BUTLER (1966)}

Lukes (1963) and Lukes and Butler (1966) proposed a classification based on the predominant histological features: (1) lymphocytic and/or histiocytic nodular; (2) lymphocytic and/or histiocytic diffuse; (3) nodular sclerosis; (4) mixed; (5) diffuse fibrosis; and (6) reticular. They claimed that there was a 'definite relationship between the histological findings, clinical stages, and survival'.

They emphasized that 'numerous terms have been proposed for the lesion with a predominance of lymphocytes but none clearly reflected the histologic character or the almost constant association with histiocytes which at times may overshadow the lymphocytic component'. There is some doubt as to what Lukes and Butler mean by the term 'histiocytes' and this is discussed below.

Using the terms lymphocytic and/or histiocytic, diffuse or nodular, Lukes and Butler (1966) recognized four histological types originating from two of the types of Jackson and Parker (1944).

1 Cases which would have been called 'paragranuloma' by Jackson and Parker (1944): these showed a predominantly lymphocytic proliferation with few histiocytes and were divided into nodular or diffuse.

2 Cases which would have been called 'granuloma' by Jackson and Parker (1944) and showed a predominance of histiocytes, divided into nodular and diffuse.

Thirty-three out of 66 lymphocytic and histiocytic cases in the series of Lukes and Butler (1966) showed histiocytic predominance. The survival time in the lymphocytic and histiocytic cases was long but failed to show such a significant difference in prognosis as to justify separation of the cases into nodular or diffuse.

The third and fourth group of Lukes and Butler, $i e$, nodular sclerosis and mixed cellularity, are subdivisions of the 'granuloma' group of Jackson and Parker (1944). In their series, Lukes and Butler (1966) considered that $40 \%$ of all their patients with

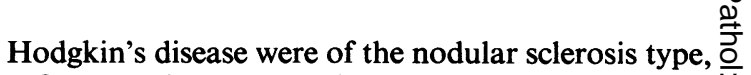
a figure which has not been approached in any of the other series; the highest incidence was $15 \% \stackrel{\vec{P}}{\rightarrow}$ (Hanson, 1964; Harrison, 1966; Cross, 1968). The음 reason for this discrepancy would appear to stem from the fact that Lukes and Butler (1966) based $\frac{\bar{\rho}}{\frac{\rho}{\sigma}}$ their subdivision largely on the amount and pattern $\stackrel{\square}{\circledR}$ of fibrous tissue; they placed great emphasis on the birefringent character of the collagenous fibrous $\rightarrow$ tissue. The presence of birefringence, in my opinion, $?$ merely reflects how long the fibrous tissue has been $\vec{\omega}$ present in the lymph gland. Nodular sclerosis was considered by Lukes and Butler (1966) to be a lesion of major prognostic significance in stage I cases i (Peters and Middlemiss, 1958), but, in their series, iv only a third of the cases of nodular sclerosis could $\vec{\sigma}$ be considered as having a good prognosis.

The description of the 'mixed' group (4) is rather 은 vague. It appears to represent the 'granuloma' type of Jackson and Parker (1944), with the following 3 cases removed: those which have fibrosis arranged in a nodular pattern and show birefringence, $i e, \stackrel{\supset}{\supset}$ nodular sclerosis; those in which normal reticulum $\vec{\bullet}$ cells predominate (histiocytes), ie, lymphocytic and/क or histiocytic diffuse; those which show advanced, ie, diffuse, fibrosis; and those composed 'predominantly of Sternberg Reed cells where pleomorphism is absent'. When all these types are removed from the 'granuloma' group, there is very $\frac{}{D}$ little remaining on which the diagnosis of a 'mixed' group can be based.

The fifth group 'diffuse fibrosis', referred to in the $\frac{3}{\sqrt{3}}$ American nomenclature as the 'fibrillary' type of Hodgkin's disease, is described by Lukes and Butler (1966) as generally composed of "compact, hypo-옹 cellular amorphous proteinaceous material that resembles precollagen'. It is not clear why this is called 'fibrosis'.

\section{RYE CLASSIFICATION: CLASSIFICATION OF LUKES AND BUTLER (1966) MODIFIED}

At the conference on Hodgkin's disease in Rye, New York, in September 1965, a nomenclature committee, with R. J. Lukes as chairman, deliberated ${ }^{N}$ on the most suitable terminology for the histological N classification of Hodgkin's disease and the following classification, based on the "histologic expressions of Hodgkin's disease described by Lukes and Butler at the conference', later published (1966), was adopted:? lymphocytic predominance, nodular sclerosis, mixed 0 cellularity, and lymphocytic depletion.

Lymphocytic predominance included the para- $\stackrel{\mathbb{D}}{\stackrel{\Omega}{\Omega}}$ granuloma type of Jackson and Parker (1944) and $\stackrel{\mathbb{Q}}{\varrho}$ also the lymphocytic and/or histiocytic types, both $\overline{0}$ nodular and diffuse, of Lukes and Butler (1966). 
Lymphocytic depletion included the diffuse fibrosis and reticular types of Lukes and Butler (1966) and the sarcoma type of Jackson and Parker (1944). Selection of the term 'lymphocytic predominance', based on the inclusion of the group lymphocytic and/ or histiocytic, nodular or diffuse of Lukes and Butler (1966), can be confusing. In more than $50 \%$ of their lymphocytic and histiocytic cases histiocytes were 'predominant'. There is an apparent contradiction in nomenclature since a case can hardly be included both under the heading of lymphocytic predominance and histiocytic predominance.

The general principle of distinguishing cases showing lymphocytic predominance or lymphocytic depletion is no doubt excellent, but, in my opinion, histologists may tend to equate lymphocytic predominance with paragranuloma and lymphocytic depletion with sarcoma. The value of the classification appears to me to lie in the division of granuloma into nodular sclerosis and mixed cellularity; as indicated above, it is not always easy to make a histological differentiation between these two groups on the criteria given by Lukes and Butler (1966) nor is there good enough correlation with prognosis.

The classification adopted at Rye thus appears to lack histological precision and fails to fulfil the need for a universally acceptable histological classification which will give a reliable guide to the likely course of the illness.

\section{TERMINOLOGY}

The Rye classification also raised the important problem of cell nomenclature. Lukes and Butler (1966) refer to 'the lymphocytic proliferation in Hodgkin's disease usually in association with varying numbers of reactive histiocytes'. The term 'histiocytic lymphoma' is used synonymously with 'reticulum cell sarcoma', when they claim support for the neoplastic nature of Hodgkin's disease and they say that the 'reticulum cell proliferation in Hodgkin's disease involves not only the abnormal reticulum cell of the Sternberg Reed type, but also a reactive histiocyte that is possibly related to the formation of fibrillar reticulum, the fibroblastic component and eventually fibrous connective tissue'. In their description of the "variation in the histological findings', they refer to 'the variety of reticulum cells in Hodgkin's disease: these include $(a)$ the abnormal reticulum cells or the Sternberg Reed cells; $(b)$ the peculiar polypoid reticulum cells found in lymphocytic and histiocytic types; and (c) reactive reticulum cells or histiocytes which have abundant pale eosinophilic cytoplasm and large vesicular nuclei without prominent nucleoli. They do not mention the presence of normal reticulum cells.

It is impossible to discuss in detail in this paper the controversy on the nomenclature of 'reticular cells' but Marshall (1956) stated that Maximow (1932), who was one of the greatest authorities on this work, considered that there were two distinct types of cells associated with the reticulin fibres of lymphatic tissue, one a phagocytic cell and the other a non-phagocytic cell able to produce all the other cell types of the reticular tissue. Gall and Mallory (1942) accepted the idea of these two cells when they used the terms 'clasmatocyte' (and its synonyms macrophage cell and histiocyte) and stem cell (and its synonym, reticulum cell). In their description of Hodgkin's lymphoma, which was considered to be polycellular, the cell components were made up of granulocytes, lymphocytes, plasma cells, clasmatocytes, and fibroblasts, all cells found in inflammatory conditions, but in addition the feature essential to Hodgkin's disease was the presence of stem cells which tended strongly to develop large multilobed or multinucleated forms. The presence of normal stem cells or reticulum cells was not mentioned. The term 'reticulum cell' has been used by some authors (Jackson and Parker, 1947) synonymously with the histiocyte or clasmatocyte.

As will be shown, I prefer to use the terms usually made acceptable in Britain and distinguish between histiocytes which occur in a wide variety of conditions such as sarcoidosis or toxoplasmosis as well as in Hodgkin's disease, and reticulum cells which are a feature of normal and reactive inflammatory lymph nodes. When Lukes and Butler stated that in Hodgkin's disease the lymphocytic proliferation was usually associated with histiocytes of reactive character, it is possible that they meant normal reticulum cells. The confusion in terminology is evident in a recent paper by Franssila, Kalima, and Voutilainen (1967); they used the classification of Lukes and Butler and described reactive histiocytic cells in such a way as to show that they referred to cells which pathologists in Britain would call 'normal reticulum cells'.

In a review of 302 patients with Hodgkin's disease at the histopathology centre of the Royal Air Force Institute of Pathology and Tropical Medicine, Halton, who presented between 1940 and 1967, a classification of Hodgkin's disease was evolved. It is believed that this is an improvement upon previous classifications and it is particularly valuable in that it provides a better basis for prognosis.

Before describing in detail the specific histological findings used in the diagnosis of Hodgkin's disease and its subsequent classification, it is necessary to define, for the purpose of classification, the cell types seen in formalin-fixed, haematoxylin-andeosin-stained paraffin sections of normal lymph glands and glands from Hodgkin's disease. 
THE CYTOLOGY OF NORMAL LYMPH GLANDS AND GLANDS FROM HODGKIN'S DISEASE

SIZE OF CELLS The size of the cell is generally described as the diameter of the area of cytoplasm. However, in a large number of the cells, it is impossible to delineate the extent of the cytoplasm and in all cell measurements it is proposed to include only the size of the nucleus.

Normal reticulum cells With a nucleus 10 to $12 \mu$ in size (Fig. 1), they are stellate in appearance; the nuclear membrane is well defined, the chromatin arranged in small, fine particles and there may be one, two, or three small darkly stained nucleoli.

Histiocytes These are 10 to $15 \mu$ in size (Fig. 2), the cell outlines are distinct, and there is abundant pale, often staining pink, slightly granular cytoplasm. The oval or kidney-shaped nucleus is usually situated at one pole of the cell, leaving a considerable amount of cytoplasm evident. The chromatin particles are fine and distributed evenly throughout the nucleus. The nucleolus is small and darkly stained.

Abnormal reticulum cells (Sternberg Reed cell) The abnormal reticulum cell (Figs. 3, 5, and 7) or Sternberg Reed cell is generally regarded as the essential prerequisite for the diagnosis of Hodgkin's disease: lymphocytes, plasma cells, eosinophils, and polymorphs indicate a reactive process but their presence is valuable in establishing the diagnosis.

The abnormal reticulum cells were originally described by Sternberg (1898) and Reed (1902), but the latter author's description of giant cells, which she claimed, were 'peculiar' to Hodgkin's disease, could fit numerous cells seen in other diseases of the reticuloendothelial system.

The form of abnormal reticulum cell which most histologists regard as pathognomonic of Hodgkin's disease is the binucleate (Fig. 6) 'mirror image' cell (Pullinger, 1932). It is significant to find these cells in a gland when Hodgkin's disease is suspected, but they may be extremely difficult to find and the diagnosis could be missed.

The varying opinions as to what constitutes a Sternberg Reed cell account for many of the diagnostic errors; Karnofsky (1966) estimated that the diagnosis of Hodgkin's disease was wrongly made in at least $20 \%$ of cases.

There has been a tendency by some authors (Dawson and Harrison, 1961; Hanson, 1964) to accept the definition of the Sternberg Reed cell given by Smetana and Cohen (1956) and an overall minimum cell diameter of $15 \mu$ was accepted. The exact definition, however, is not completely clear. Smetana and Cohen indicated that the nuclear membrane had many outcroppings and folds that often caused the cell to appear multinucleated.
Later they also indicated that the cells with single, $\frac{\stackrel{0}{\vec{\sigma}}}{-}$ not folded, nuclei and amphoteric nucleoli were not $\Rightarrow$ : diagnostic of Hodgkin's disease. Dawson and $\stackrel{?}{+}$ Harrison, however, described Sternberg Reed cells: with single round nuclei and also cells with two oro more discrete nuclei.

Lukes and Butler (1966) also emphasized theo variation in the cytological features of Sternberges Reed cells, but they regarded only cells with $\overrightarrow{-}$ characteristic 'multinucleated, binucleated and lob-: ated forms with huge inclusion-like nucleoli' as $\vec{\omega}$ reliable and essential for the diagnosis of Hodgkin's? disease, and they considered that the mononuclearo forms with similar nuclear and cytoplasmic appear N ance could be found in lymphoid reactions of viraliu infections.

The criteria of Smetana and Cohen (1956) and Lukes and Butler (1966) are considered to be too? restrictive and a more acceptable description of the $\overrightarrow{-}^{-}$ Sternberg Reed cells is proposed as follows. The size varies from 15 to $60 \mu$. The nucleus is enlargedo in relation to the amount of cytoplasm. Uptake of the haematoxylin stain varies. The size of the nucleuso varies and there is pronounced infolding. The ${ }^{\Theta}$ chromatin is irregularly distributed. It may have $\mathrm{a}$ trabecular arrangement, or appear as small denses clumps with indefinite outlines, particularly around the nuclear membrane which is thickened. Chromatinő is scanty around the nucleolus, producing a halo effect. The nucleolus is large, irregularly shaped, and $\overrightarrow{\overrightarrow{7}}$ usually stains eosinophilic. Abnormal mitosis is present in the Sternberg Reed cells. Necrobiosis? is a feature in some of the Sternberg Reed cells.

The tendency for Sternberg Reed cells to undergo necrobiosis (Fig. 16) in Hodgkin's disease was. emphasized by Jackson and Parker (1944). Little attention has been given to these cells by subsequent authors. They are degenerating and pyknotic cells, the cytoplasm is indefinite, and the nucleus, with little chromatin pattern, is pleomorphic, stains? heavily with the haematoxylin stain, and is easily distinguishable from the other cells in the lymph gland. Although not pathognomonic, the diagnosis of Hodgkin's disease can seldom be made in their absence.

\section{PRESENT SERIES}

The present study is based on 302 cases of ma lignant lymphoma occurring in Royal Air Force patients from 1940 to 1967 . Attention was directed to the correlation between the histological findings in the lymph gland and the survival time of the? patient. Many criteria were studied and it was found that certain ones enable Hodgkin's disease to be subdivided on morphological grounds. Normal ando 
abnormal reticulum cells were present in varying numbers and transitions were observed fairly readily as described by Dawson and Harrison (1961). The criteria were the proportion of mature lymphocytes (Fig. 3); the presence of plentiful mature histiocytes (Fig. 9); the presence of a pronounced nodular fibrous tissue pattern (Fig. 14); and the proportion of abnormal reticulum cells and their degree of anaplasia (Figs. 4, 6, 7, and 8). Other criteria, such as the presence of eosinophils, plasma cells, and polymorphonuclear leucocytes, were investigated but were found to lack significant prognostic importance.

\section{HISTOLOGICAL CLASSIFICATION}

On histological grounds, therefore, it was possible to divide patients with Hodgkin's disease into three groups.

1 RETICULAR GROUP Composed essentially of the normal reactive cells and abnormal reticulum cells, but with no significant number of histiocytes and no definite nodular fibrous pattern.

2 HISTIOCYTIC GROUP In addition to the normal reactive cells and abnormal reticulum cells, there were large numbers of histiocytes.

3 NODULAR SCLEROSIS GROUP The significant findings were the formation of a nodular fibrous pattern, which consisted of collagenous fibrous bands encircling lymphoid tissue, amongst which were characteristic large abnormal reticulum cells with abundant clear cytoplasm and irregularly shaped multilobed nuclei.

By assessing the relative numbers of lymphocytes and abnormal reticulum cells in the lymph gland and the degree of anaplasia of the abnormal reticulum cells, each group was divided into well differentiated and poorly differentiated. In the reticular group it was feasible to divide into three types, lymphocytic, well differentiated, and poorly differentiated.

\section{RETICULAR GROUP}

LYMPHOCYTIC TYPE (PARAGRANULOMA OR BENIGN HODGKIN'S DISEASE) Twenty-six (9\%) patients (Figs. 3 and 4) were thus classified.

The use of the term 'paragranuloma' to indicate a lesion with a preponderance of lymphocytes is considered to be unsatisfactory, as Hodgkin's disease is no longer thought to be a granulomatous condition. Benign Hodgkin's disease is also unsatisfactory as this type of Hodgkin's disease is a lethal condition. Therefore the term reticular lymphocytic type, indicating those cases in which there are large numbers of normal lymphocytes and few abnormal reticulum cells, was selected as being more appropriate.

Follicular pattern In 21 of 26 glands the normal follicular pattern was completely obliterated, in five there was partial loss. The capsule was thickened in five glands, but not in 21. A lobular pattern was present in 18; eight showed a diffuse pattern. The lobular pattern, when present, was poorly defined and the tissue was divided into rounded masses by reticulin bands, best demonstrated by reticulin stains; the degree of fibrosis and the cellular composition of the lobule did not resemble the appearances seen in either nodular sclerosis or giant follicular lymphoma.

Lymphocytes There was an even proliferation of mature lymphocytes throughout the gland; they appeared to be normal on routine histological examination. Lymphocytes formed from 75 to $95 \%$ of the cell population of the gland; no mitotic figures were seen.

Reticulum cells Normal reticulum cells, moderately numerous, were easily identified throughout the gland, but the characteristic feature was the presence of abnormal reticulum cells, which varied in size from 12 to $25 \mu$. They were found diffusely spread throughout the gland, and never in clusters. The majority of the cells had a single nucleus, some were binucleate, and an occasional cell had three nuclei. The nuclear membrane was markedly infolded; the chromatin pattern was delicate and the nucleolus usually small. Necrobiotic cells, though scanty, were easily identified.

Other cells Normal histiocytes and fibroblasts were scanty; a small number of plasma cells were frequently present, but eosinophils and polymorphs were absent.

WELL DIFFERENTIATED TYPE Seventy-seven ( $25 \%)$ patients (Figs. 5 and 6) were of this type.

Follicular pattern The normal follicular pattern was completely obliterated in 62 of 78 glands; in 16 there was partial destruction. The amount of fibrosis was variable. In 27 glands there was no thickening of the capsule and general fibrosis was minimal; in 51 glands there was marked thickening of the capsule, and in 12 glands there were irregular areas or bundles of fibrous tissue throughout the whole or part of the gland. Although some of the fibrous tissue was birefringent, it did not form the distinctive pattern seen in nodular sclerosis. Necrosis was present in three cases.

Lymphocytes The normal mature lymphocyte was the predominant cell type forming between 50 and $75 \%$ of the cell population. 


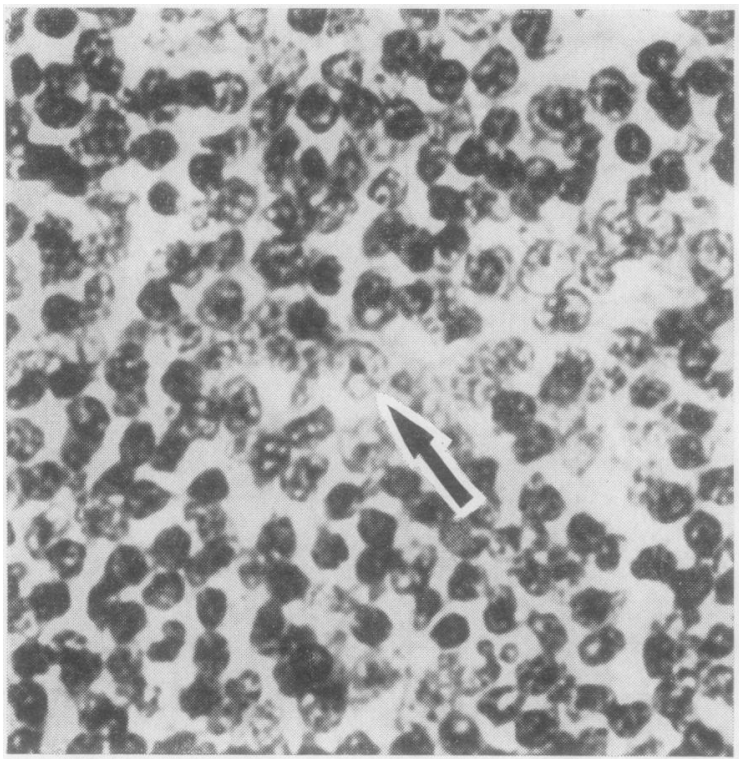

FIG. 1.

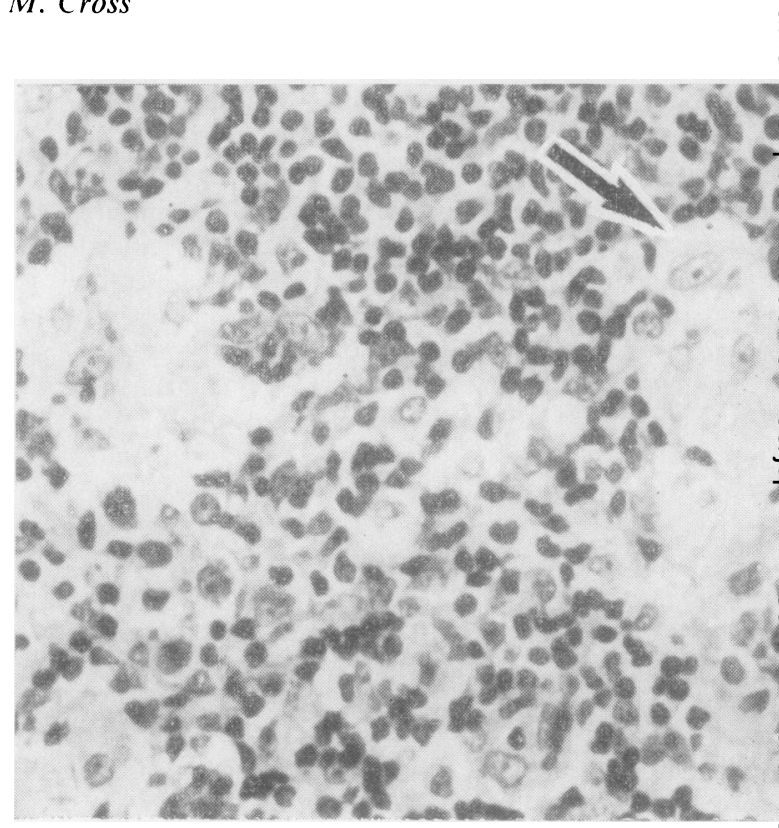

FIG. 2.

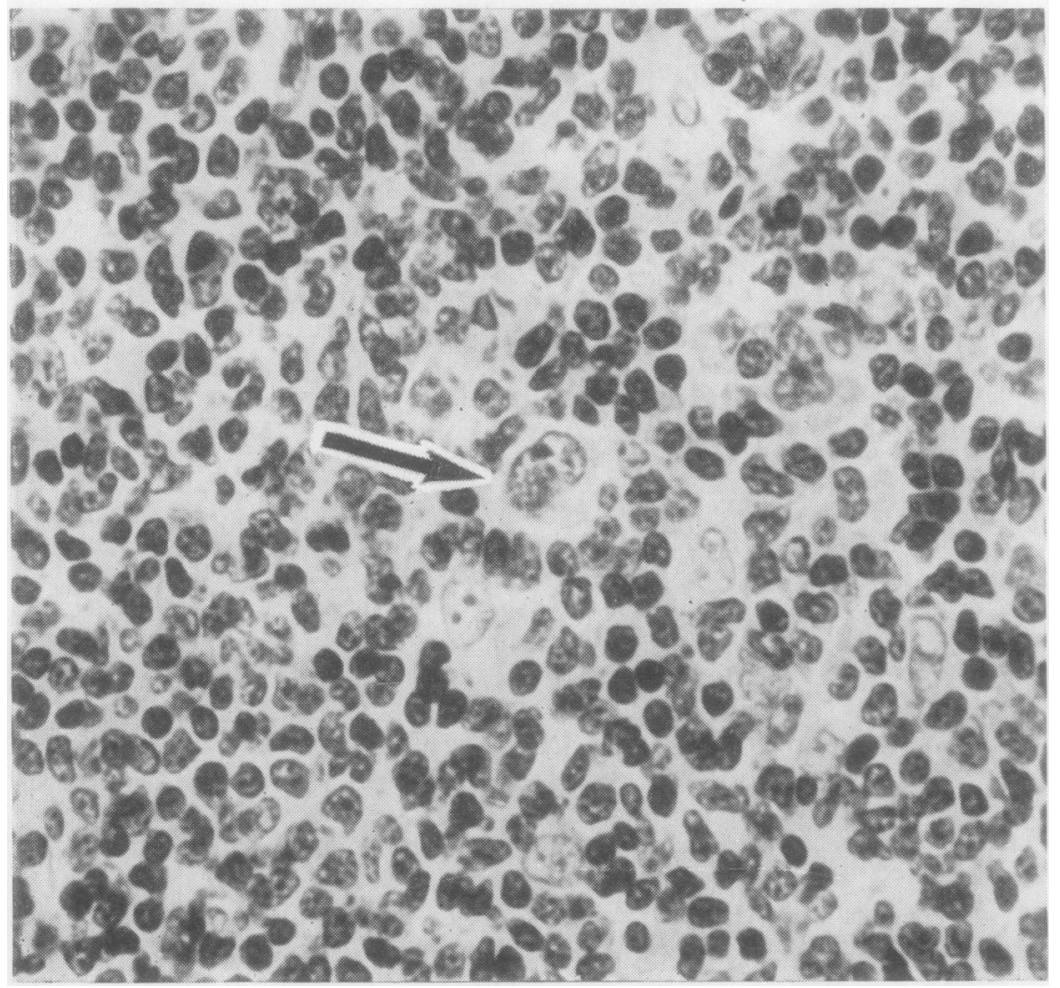

FIG. 1. Normal lymph gland. Normal reticulum cell (arrow) with vesicular nucleus and small nucleolus. Cytoplasm ill-defined. $H \& E \times 400$.

FIG. 2. Reactive lymph node 응 showing epithelioid histiocytes with oval nucleus (arrow), smallo nucleoli, and bulky cytoplasm. $H \& E \times 200$.

FIG. 3. Reticular group: lymphocytic type (paragranuloma) showing predominance of lymphocytes and a central abnormal reticulum cell (arrow). A few normal reticulum cells are also visible. $H \& E \times 400$.

\section{(1)} 을 

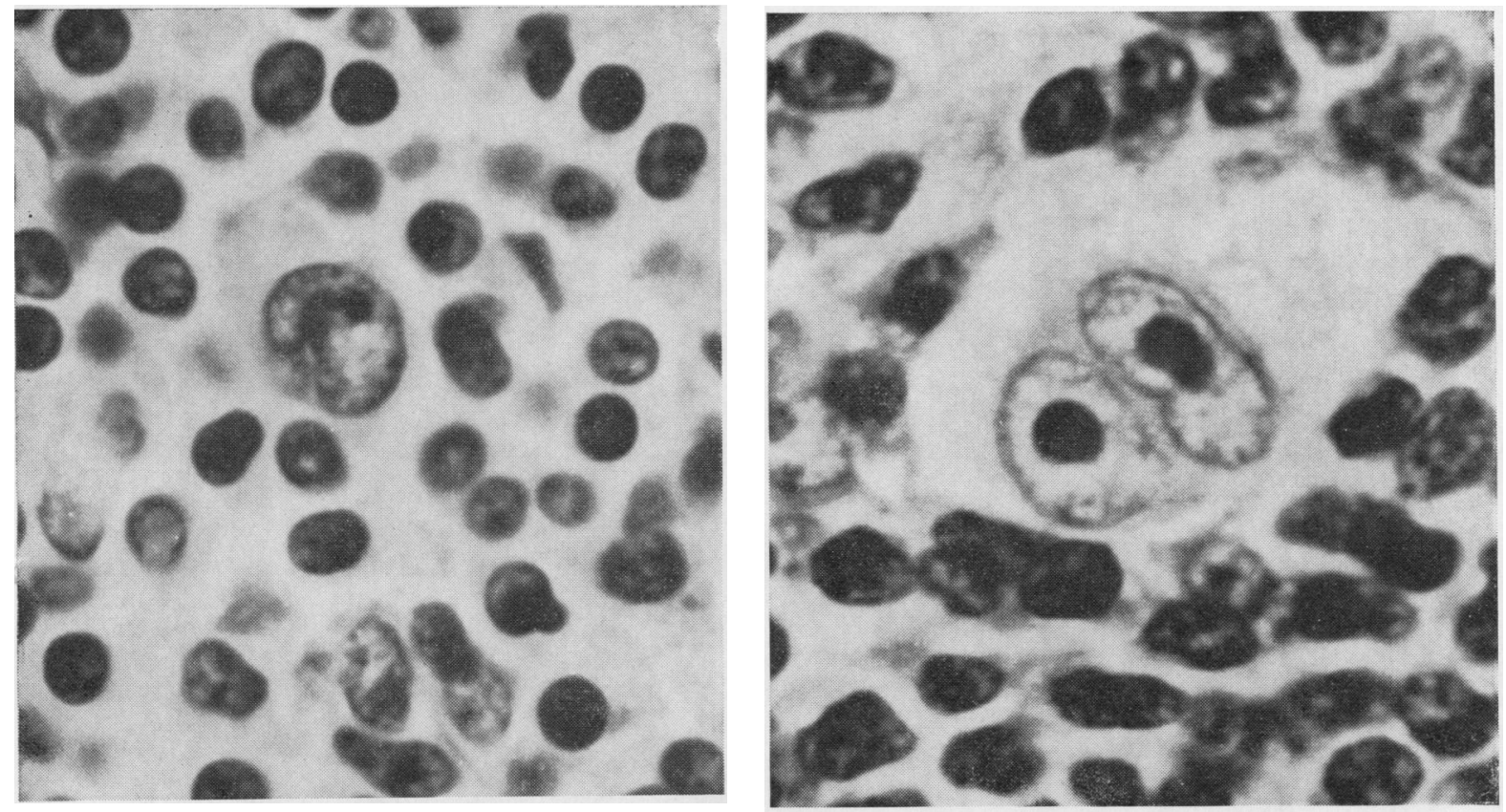

FIG. 4.

FIG. 6.

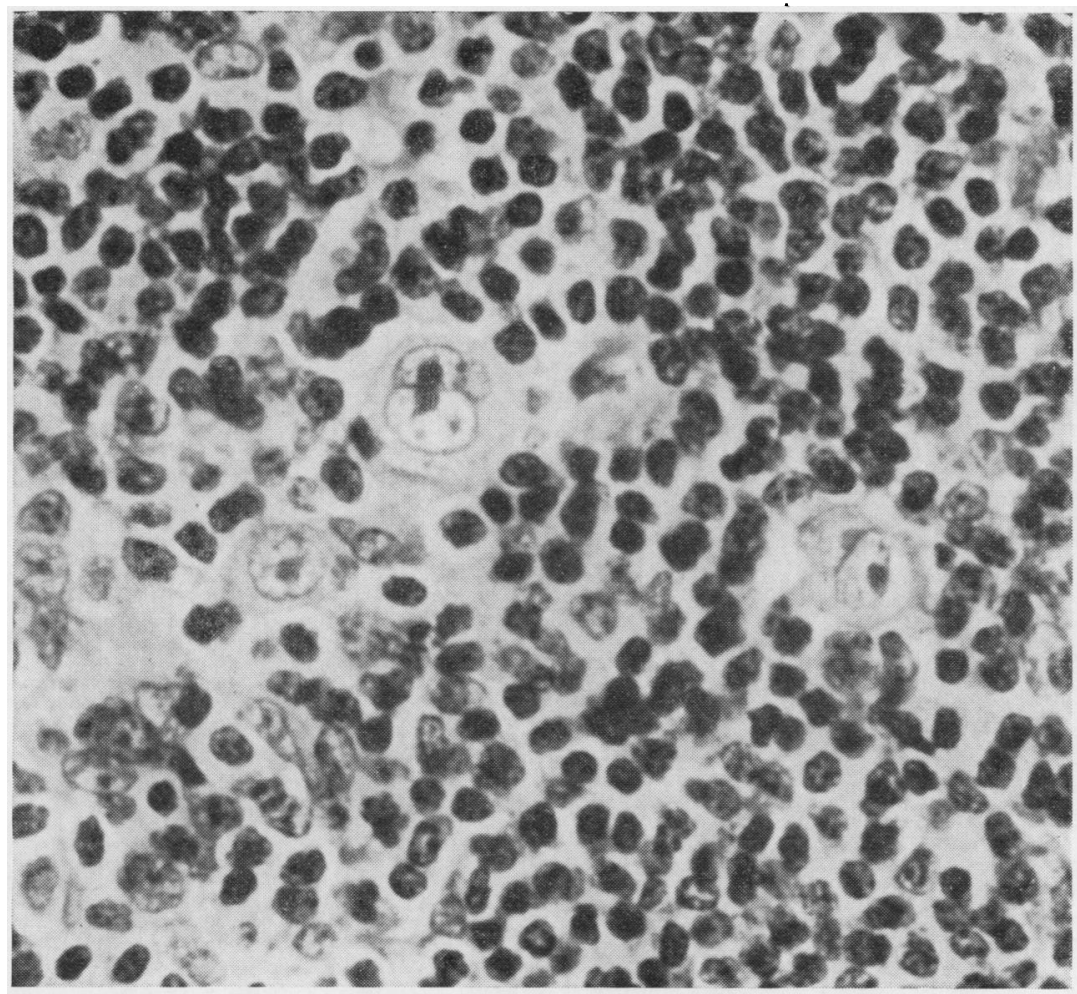

FIG. 4. Reticular group:

lymphocytic type (paragranuloma) showing a rather small abnormal reticulum cell (nucleus $20 \mu$ diameter). $H \& E \times 900$.

FIG. 5. Reticular group: well differentiated type. Lymphocytes still predominant but abnormal reticulum cells more numerous and larger. $H \& E \times 400$.

FIG. 6. Reticular group: well differentiated type. Binucleate abnormal reticulum cell (Sternberg Reed) with large nucleoli and perinucleolar halo. $H \& E \times 900$.

FIG. 5 . 


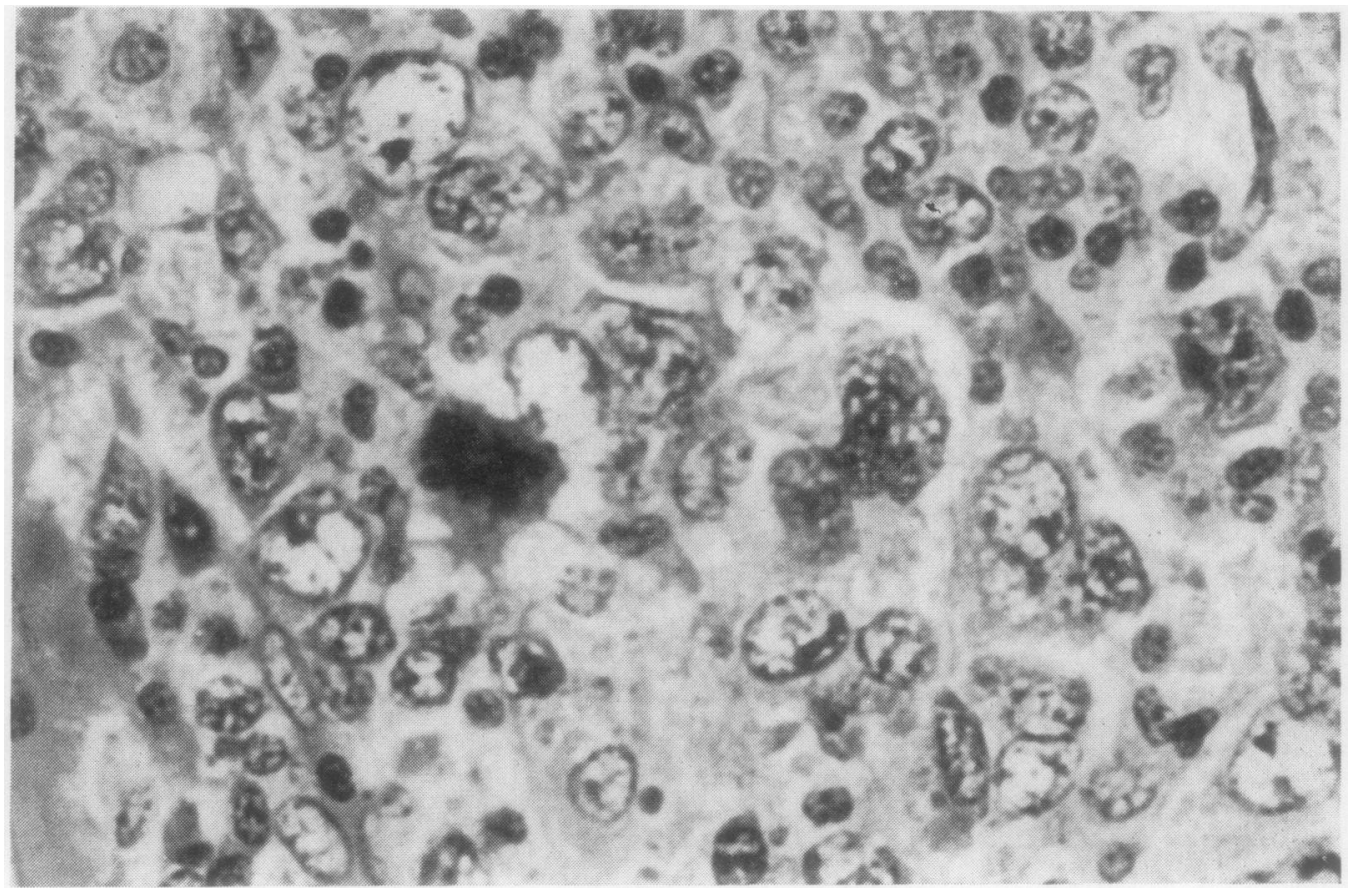

FIG. 7.

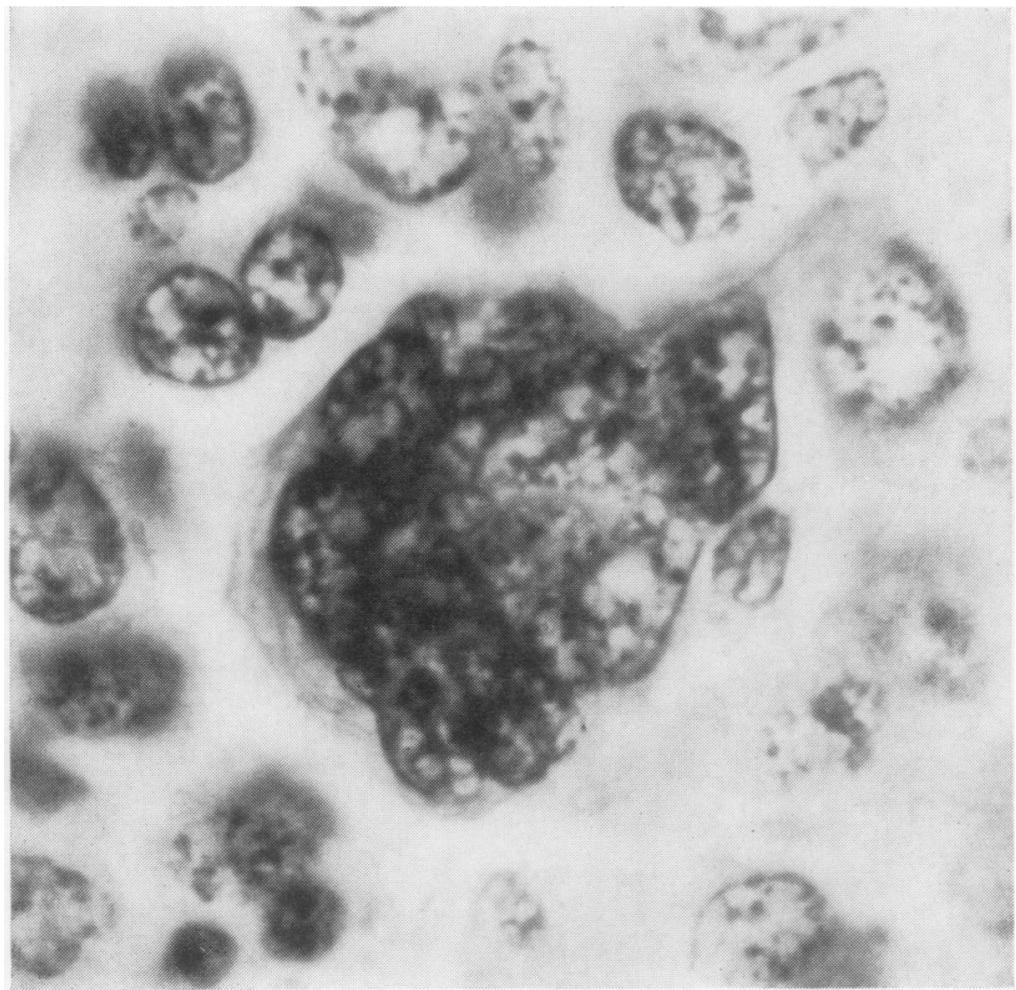

FIG. 7. Reticular group: poorly differentiated type. Lymphocytic depletion, abnormal reticulum cells predominate, wide variation of cell size and morphology. $H \& E \times 400$.

FIG. 8. Reticular group: poorly differentiated type. Grossly abnormal reticulum 음. cell. The nucleus is hyperchromatic, multilobed, and or shows bizarre configurations. N $H \& E \times 900$.

FIG. 8. 


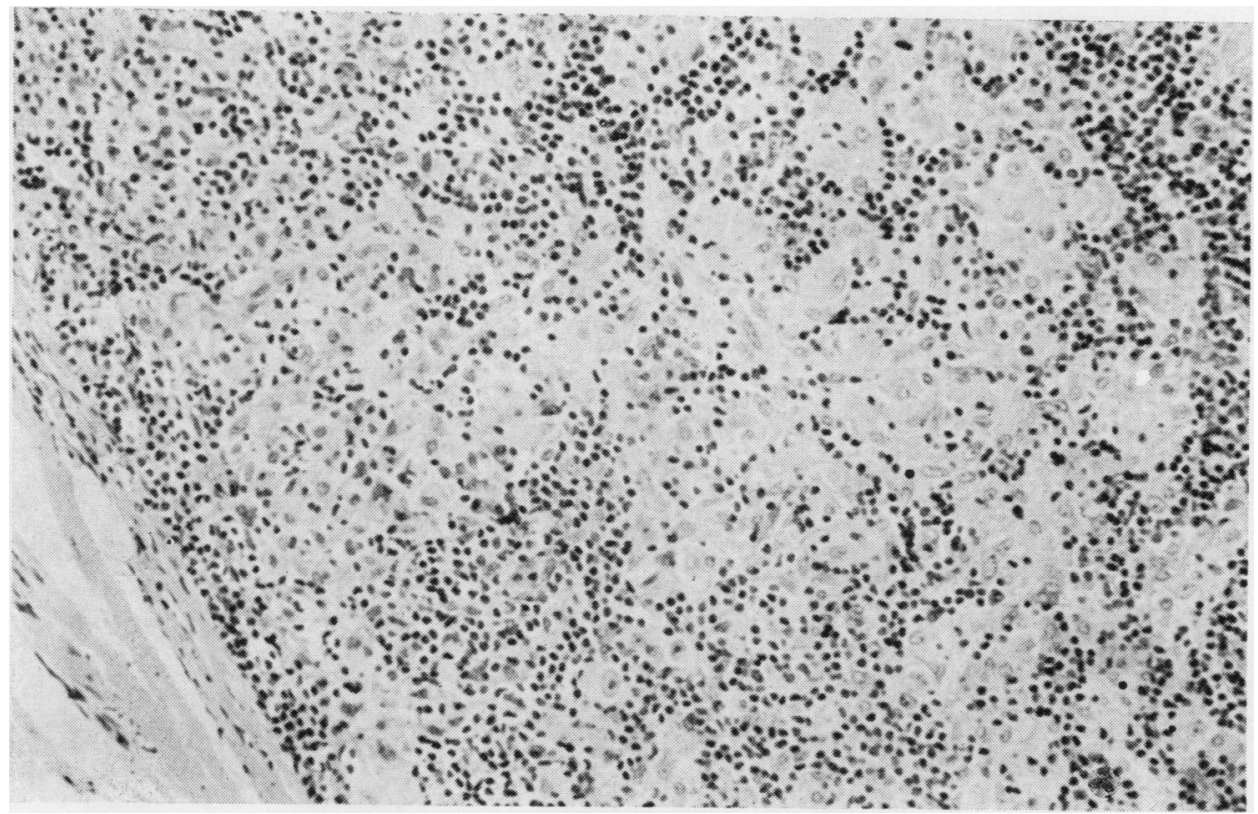

FIG. 9. Histiocytic group: well differentiated type. Most of this field is composed of lymphocytes and epithelioid histiocytes. $H \& E \times 100$.

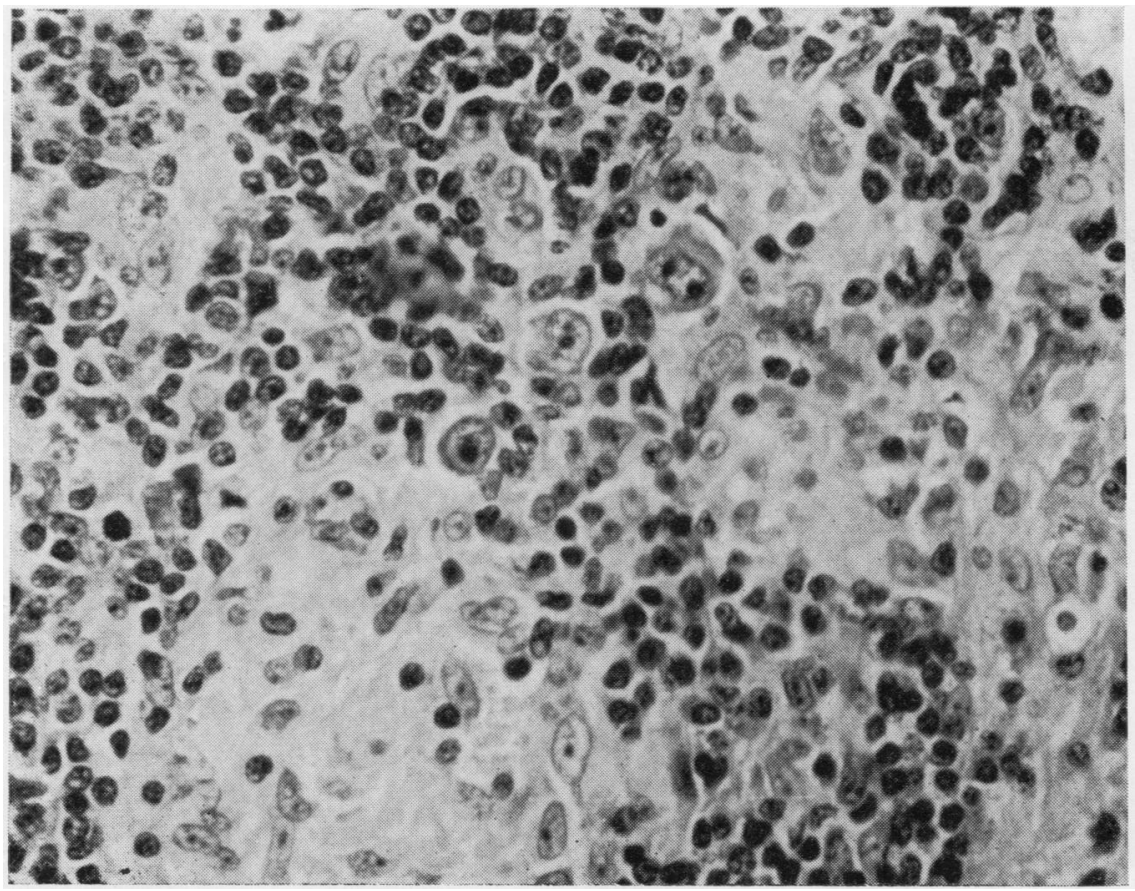

FIG. 10. Histiocytic group: well differentiated type. This shows lymphocytes, epithelioid histiocytes, and a cluster of abnormal reticulum cells on which the diagnosis of Hodgkin's disease is confirmed. $H \& E \times 400$. 


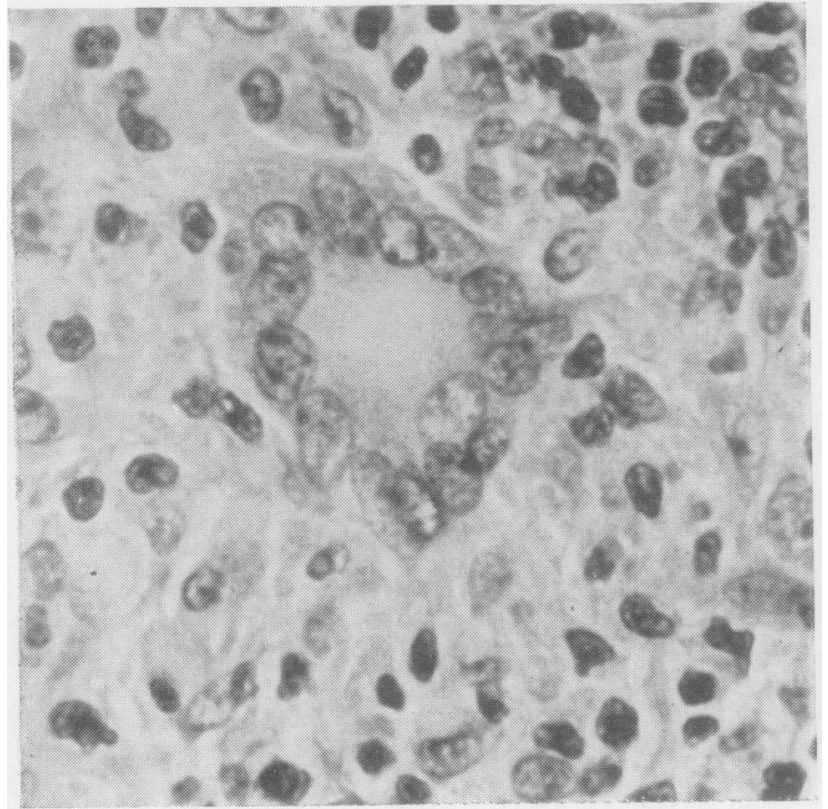

FIG. 11.

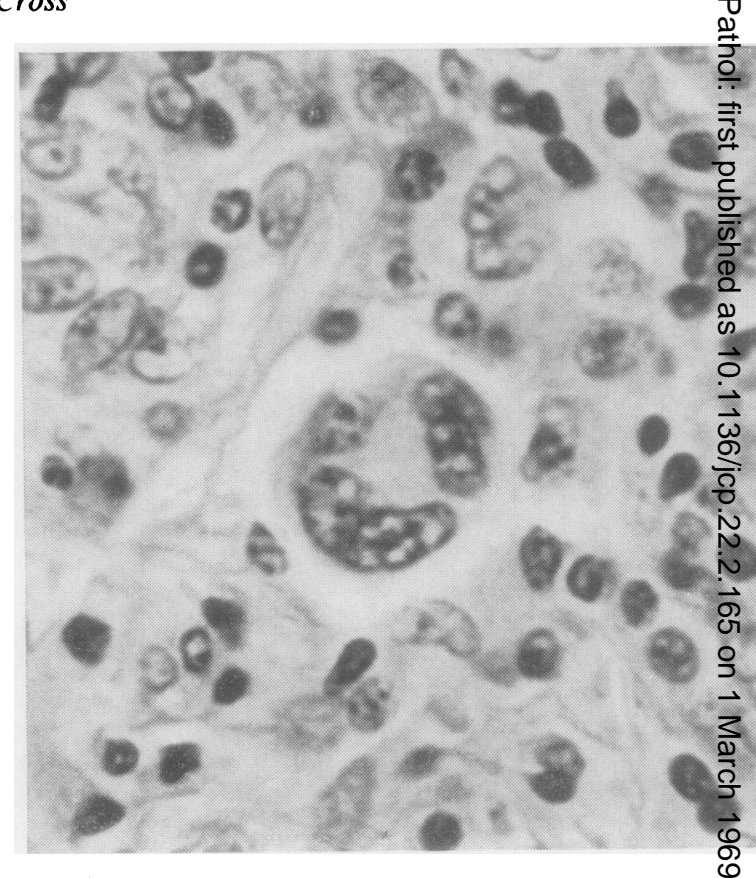

FIG. 13.

FIG. 11. Histiocytic group: well differentiated type showing epithelioid histiocytes with a Langhans' type giant cell. .0 Abnormal reticulum cells not seen in this field. $H \& E \times 400$.

FIG. 13. Histiocytic group: poorly differentiated type. A large abnormal reticulum cell with peripheral nuclei and prominent nucleoli superficially resembling a Langhans' giant cell. The rest of the field shows histiocytes and lymphocytes.ٌ $H \& E \times 400$.

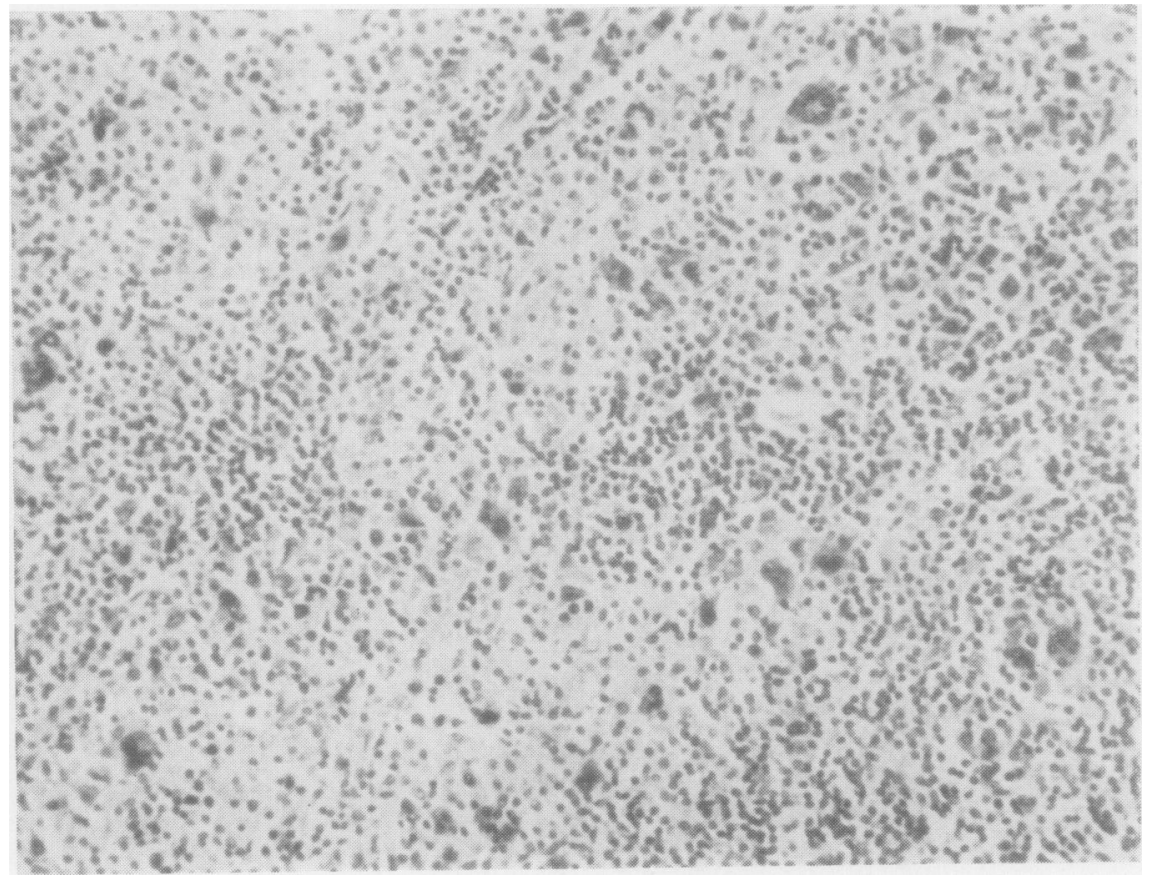

FIG. 12. Histiocytic group poorly differentiated type. Lymphocytes and abnorma?. reticulum cells form most $8 f$ this field but groups of smaß口 pale epithelioid histiocytes \&ुe still visible. $H \& E \times 100$. 


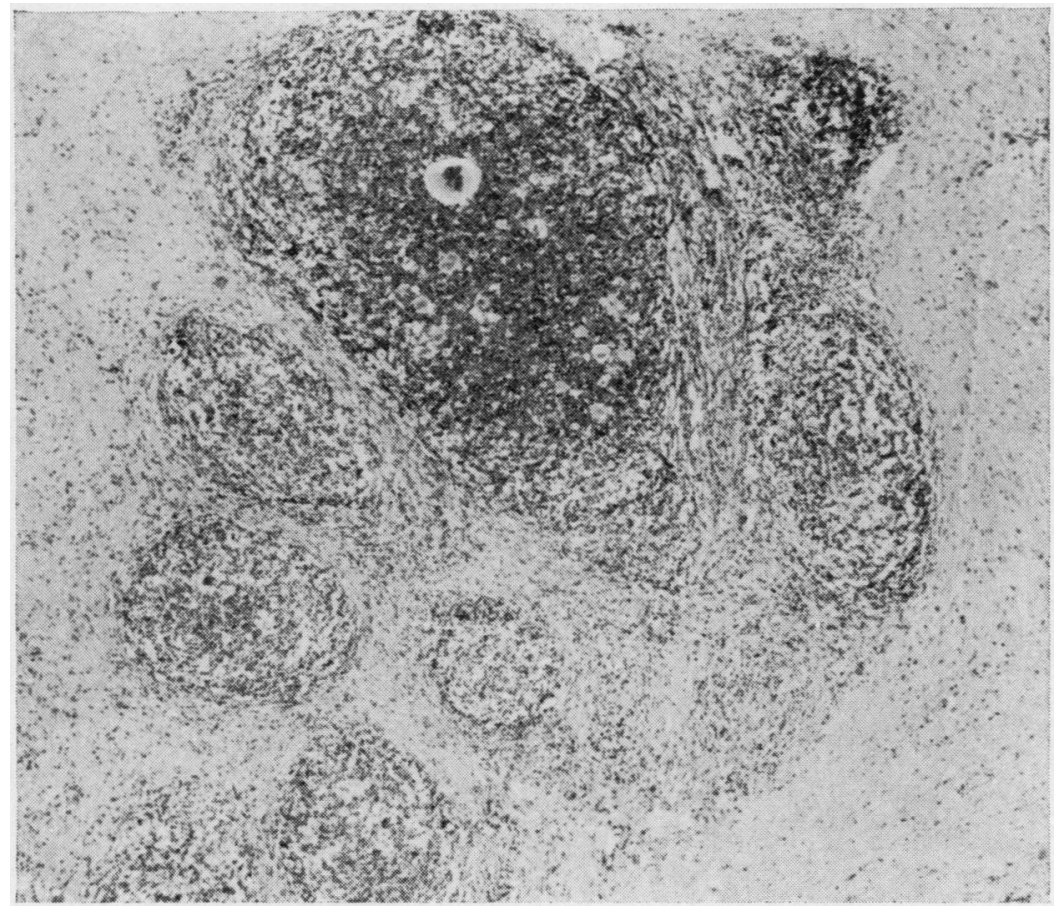

FIG. 14. Nodular sclerosis group: well differentiated type. Dense collagen divides up lymph node into nodules containing lymphocytes and paler abnormal reticulum cells. One large lacuna cell is seen. $H \& E \times 25$.

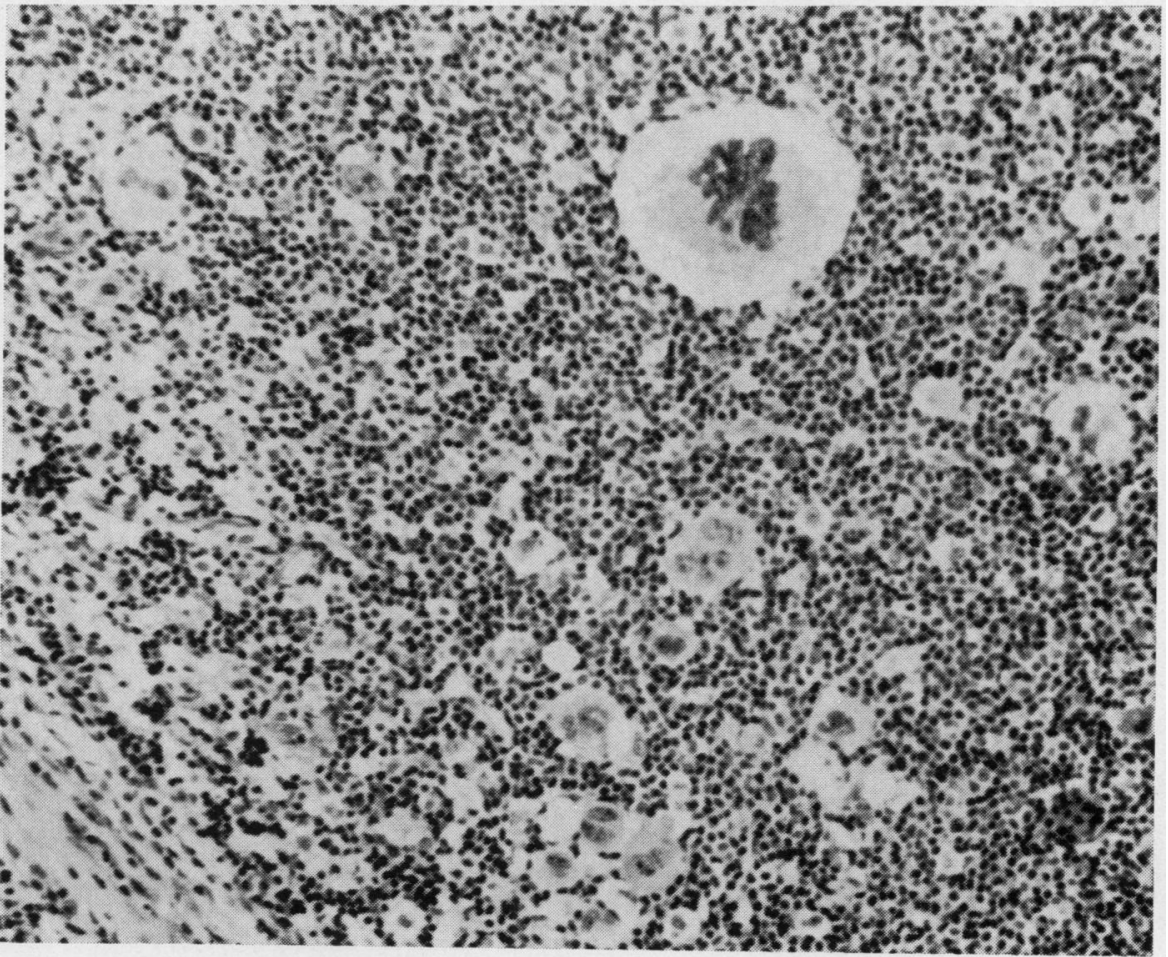

FIG. 15. Nodular sclerosis group: well differentiated type. Higher magnification of part of Figure 14.

$H \& E \times 100$. 


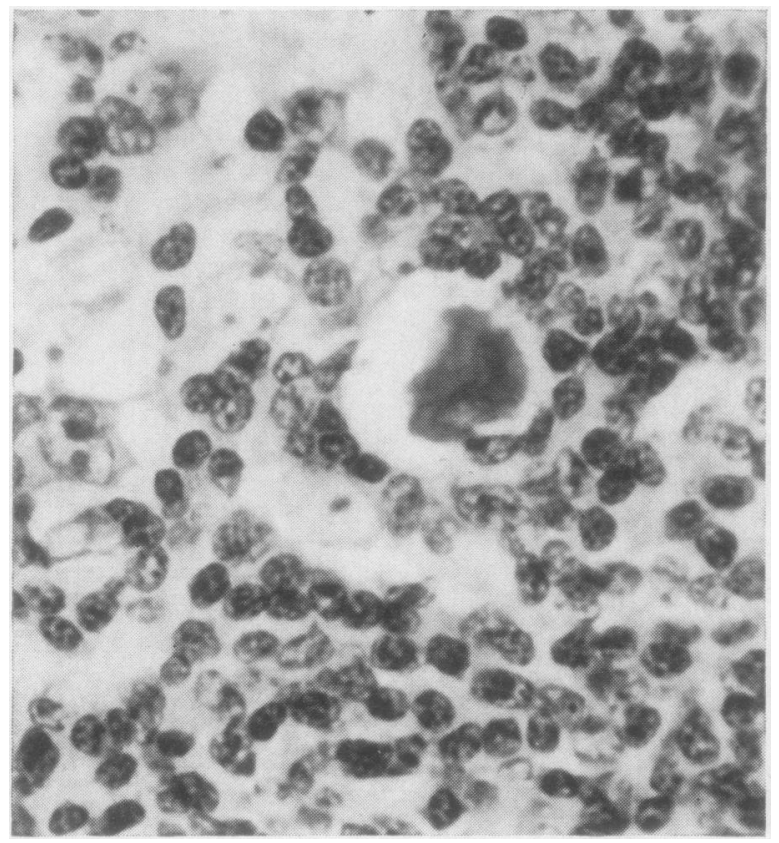

FIG. 16. Nodular sclerosis group: well

differentiated type. One necrobiotic cell is seen. This cell is seen in all types of Hodgkin's disease $H \& E \times 400$.

FIG. 17. Nodular sclerosis group: poorly differentiated type. The nodular pattern is similar to that in Figure 14, but lymphocytes no longer predominate. $H \& E \times 25$.

FIG. 16 .

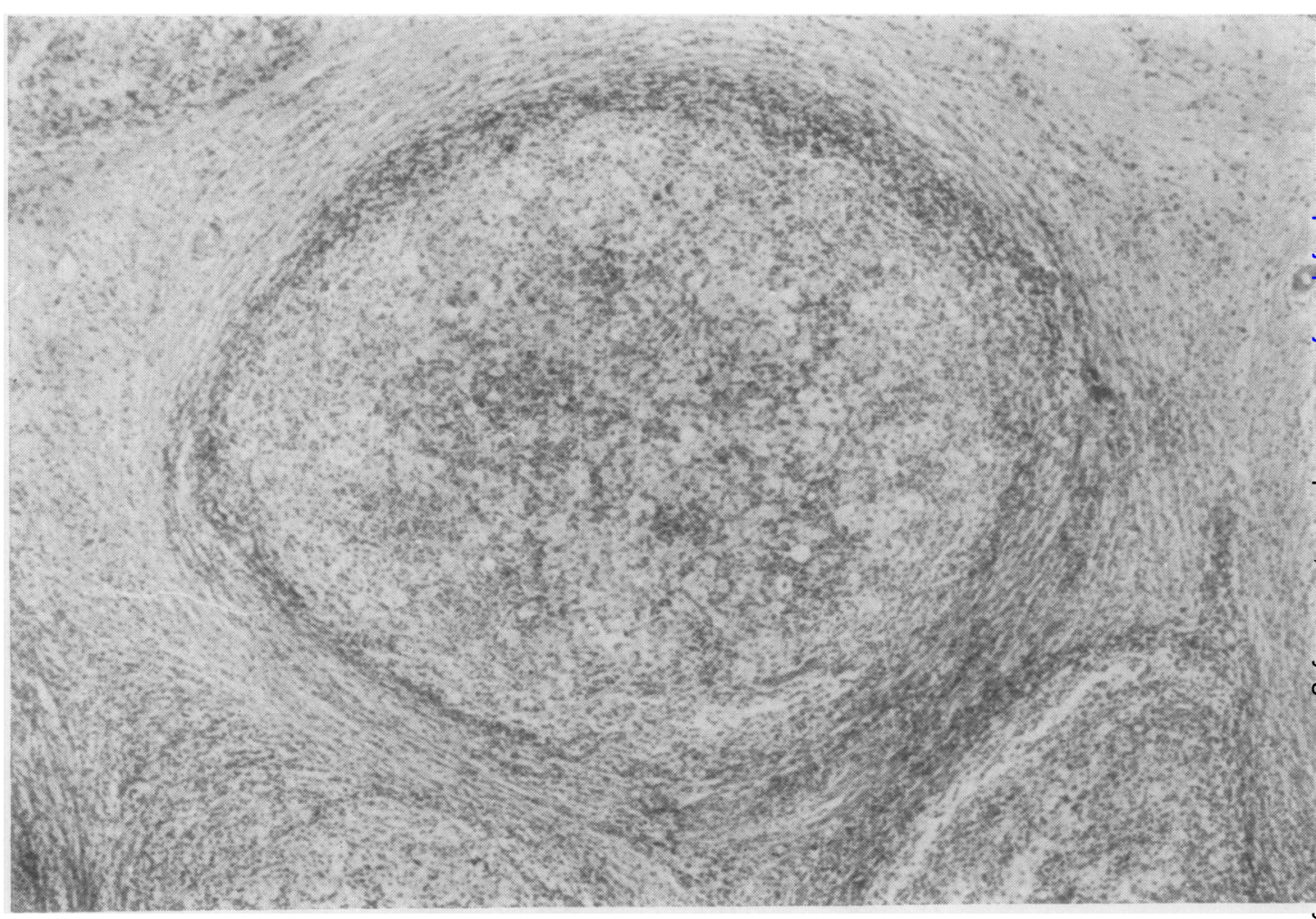

FIG. 17. 


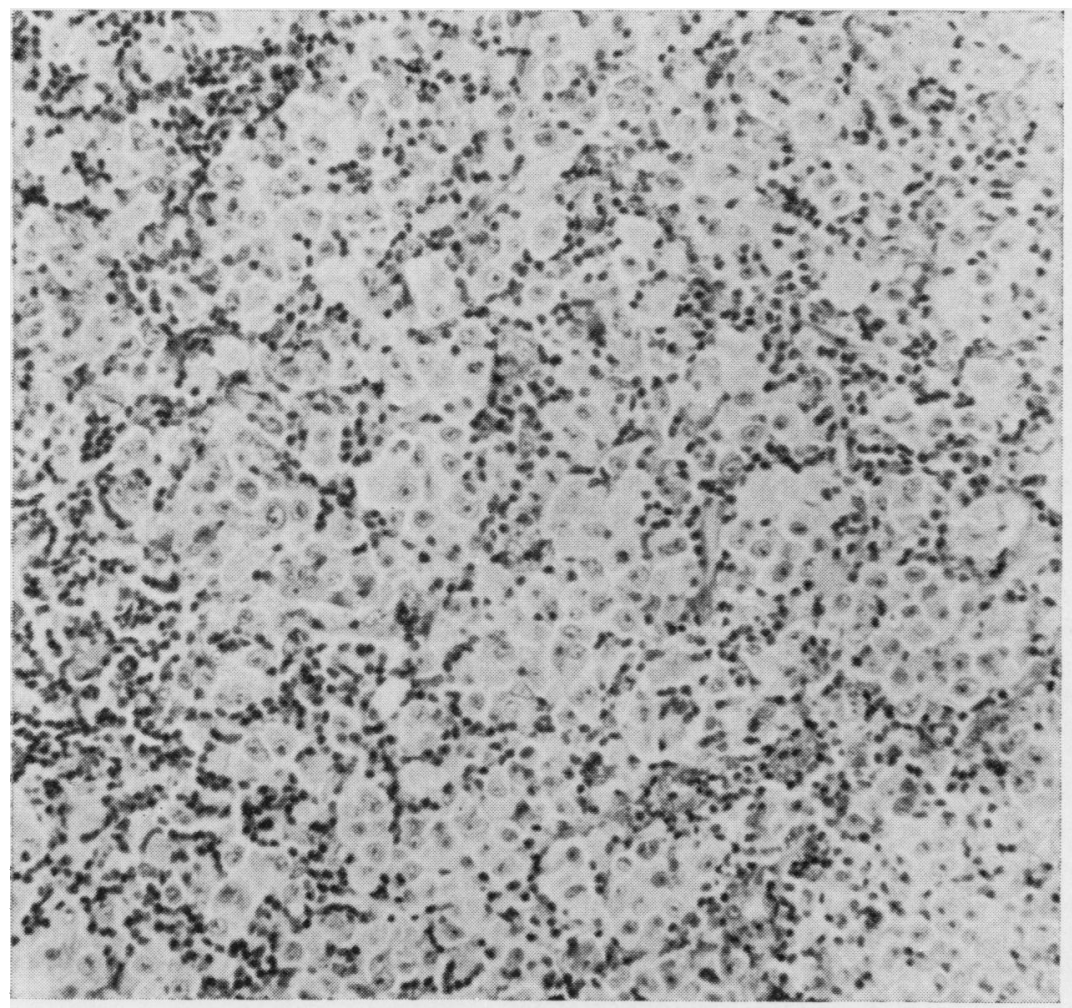

FIG. 18. Nodular sclerosis group: poorly differentiated type. Higher magnification of Figure 17, to show the predominance of abnormal reticulum cells. $H \& E \times 100$.

Reticulum cells Normal reticulum cells could be recognized, but the abnormal cells outnumbered them, and in contrast to the lymphocytic type, they were arranged in irregular collections throughout the gland. Pleomorphism and hyperchromasia were prominent features, and although there were a number of cells with a single nucleus, the proportion of binucleated cells was greater than in the lymphocytic type. In addition, the infolding of the nucleus was more pronounced, the chromatin pattern was coarser and arranged in irregular clumps: the halo surrounding the nucleolus was more pronounced than in the reticular lymphocytic type: the nucleolus was large, round, or sausage shaped, often staining bright red. Necrobiotic cells were a prominent feature; they varied considerably in size and pattern, and were easily recognized. In the abnormal reticulum cells mitotic figures were present in varying numbers.

Other cells Eosinophils and plasma cells were always present in varying numbers, diffusely spread throughout the gland, or collected in groups.

POORLY DIFFERENTIATED TYPE Ninety-seven (35\%) patients (Figs. 7 and 8 ) were thus classified.
The exact definition of the type called Hodgkin's sarcoma by Jackson and Parker (1944) has always caused some difficulty. The incidence recorded by various authors, as shown in Table I, varied from 1 to $10 \%$. Other authors (Lumb and Newton, 1957; Symmers, 1958) considered it impossible to separate Hodgkin's sarcoma from reticulum cell sarcoma. Hilton and Sutton (1962) observed how rarely the diagnosis of Hodgkin's sarcoma $(1 \%)$ was made in their series, and they considered that socalled Hodgkin's sarcoma was better regarded as reticulum cell sarcoma. In the proposed classification the term 'sarcoma' has been avoided; as a result of the emphasis placed upon the abnormal reticulum cells, cases, which previously would have been called sarcoma, are included in the poorly differentiated types of the various groups.

Follicular pattern In 96 of 99 glands the normal follicular pattern was completely obliterated. In 30 the capsule was thickened and invaded by abnormal reticulum cells, which were often seen in the perinodal tissue. In 27 a variable amount of fibrous tissue was present, arranged in irregular bundles. Areas of necrosis were present in $\mathbf{4 8}$ glands.

Lymphocytes Less than $50 \%$ of the cell popula- 
tion were normal lymphocytes, and they were often found in small groups.

Reticulum cells Normal reticulum cells were rarely found, and abnormal reticulum cells comprised 50 to $80 \%$ of the total cells. Pleomorphism and hyperchromasia were pronounced. Multinucleated cells were prominent, and typical binucleate cells were easily found, but a high proportion of the cells had a single nucleus. The chromatin pattern in most of the cells was coarse and irregularly dispersed throughout the nucleus. The nucleolus was large, mainly round, and appeared bright red. Abnormal mitotic figures were numerous. The presence of large numbers of necrobiotic cells was a special feature.

Other cells Plasma cells and eosinophils were prominent, and numbers of polymorphs were associated with necrotic areas.

ANAPLASIA IN THE ABNORMAL RETICULUM CELLS Apart from the proportions of the different cell types used to divide cases into well and poorly differentiated there was also a difference in the degree of anaplasia of the abnormal reticulum cells in the three types; those in the lymphocytic reticular were less anaplastic than those in the well differentiated reticular type, and those in the poorly differentiated reticular type showed the most anaplastic features of all. A summary of the criteria used is seen in Table II.

Lymphocytic reticular type The majority of the abnormal reticulum cells were single (Fig. 4), but binucleated and multinucleated cells were occasionally seen in which all the lobes had similar characteristics. The nuclear membrane was thin with $\frac{\mathrm{O}}{.}$ a few dots upon it. The chromatin pattern was $\overrightarrow{\vec{F}}$ delicate and lightly stained. The nucleolus was $\stackrel{\text { ? }}{+}$ generally small and stained weakly eosinophilic.

Well differentiated type Although the majority $\frac{\bar{\sigma}}{\bar{N}}$ of the abnormal cells had single nuclei the number of $\frac{\bar{\sigma}}{\vec{\sigma}}$ binucleated and multinucleated (Fig. 6) cells was $\stackrel{\varnothing}{\circ}$ greater than in the lymphocytic type. The nuclear membrane was thickened and the chromatin pattern $\vec{\circ}$ was coarse and arranged in irregular collections. There was a characteristic lack of chromatin round $\vec{\omega}$ the nucleolus which produced a 'halo' effect. The nucleolus was invariably four times the normal size, $\frac{8}{0}$ and stained bright red with haematoxylin and eosin. N

Poorly differentiated reticular type The out- iv standing feature was the degree of pleomorphism $\vec{D}$ and hyperchromatism with large numbers of multi- $G$ nucleated cells (Fig. 8). In the more primitive types, $\frac{9}{9}$ however, the majority of the cells had a single nucleus and binucleated cells were sometimes difficult to identify.

The nuclear membrane was thickened and the chromatin arranged in dense clumps, again $\bullet$ producing a 'halo' effect around the large nucleolus. Although there was marked infolding of the nucleus, distinct lobules were rarely seen, and the nucleus presented large irregular amoeboid projections, producing bizarre configurations. Abnormal mitotic figures were plentiful.

\section{HISTIOCYTIC GROUP}

In addition to the abnormal reticulum cells, the findings which placed a lymph gland in the histiocytic

TABLE II

SUMMARY OF CRITERIA USED TO SEPARATE THE RETICULAR GROUP INTO THREE TYPES

\begin{tabular}{|c|c|c|c|c|}
\hline Type & Pattern & Lymphocytes & Other Cells & Abnormal Reticulum Cells \\
\hline Lymphocytic & $\begin{array}{l}\text { Fine lobular pattern, } \\
\text { little fibrosis, no } \\
\text { necrosis }\end{array}$ & $\begin{array}{l}\text { More than } 75 \% \text { of the } \\
\text { cell population }\end{array}$ & $\begin{array}{l}\text { Normal reticulum cells, } \\
\text { fibroblasts, and plasma } \\
\text { cells present in small } \\
\text { numbers; eosinophils } \\
\text { extremely scanty }\end{array}$ & $\begin{array}{l}\text { Little pleomorphism; less than } 10 \% \\
\text { of cell population, arranged } \\
\text { diffusely; single cells common and } \\
\text { binucleated cells difficult to find; } \\
\text { chromatin pattern fine and evenly } \\
\text { distributed; nucleolus small, often } \\
\text { absent }\end{array}$ \\
\hline Well differentiated & $\begin{array}{l}\text { Coarser pattern } \\
\text { with fibrosis more } \\
\text { prominent, occasional } \\
\text { necrosis }\end{array}$ & $\begin{array}{l}50 \text { to } 75 \% \text { of the cell } \\
\text { population }\end{array}$ & $\begin{array}{l}\text { Moderate numbers of } \\
\text { normal reticulum cells; } \\
\text { large numbers of } \\
\text { eosinophils and plasma } \\
\text { cells; few polymorphs }\end{array}$ & $\begin{array}{l}\text { Moderate pleomorphism; average } \\
10 \text { to } 40 \% \text { of cell population; } \\
\text { arranged in clusters, moderate } \\
\text { numbers of binucleated and } \\
\text { multinuceated cells present; } \\
\text { chromatin pattern coarse and } \\
\text { distributed in clumps; nucleolus } \\
\text { large, eosinophilic and invariably } \\
\text { present }\end{array}$ \\
\hline Poorly differentiated & $\begin{array}{l}\text { Coarse pattern with } \\
\text { fibrosis, necrosis } \\
\text { invariably present }\end{array}$ & $\begin{array}{l}\text { Less than } 50 \% \text { of the } \\
\text { cell population }\end{array}$ & $\begin{array}{l}\text { Few normal reticulum } \\
\text { cells; large numbers of } \\
\text { eosinophils and plasma } \\
\text { cells; large numbers of } \\
\text { polymorphs }\end{array}$ & $\begin{array}{l}\text { Marked pleomorphism; more than } \\
\mathbf{4 0} \% \text { of cell population arranged in } \\
\text { sheets and clusters; many single } \\
\text { nuclear cells; binucleated and } \\
\text { multinucleated cells found in large } \\
\text { numbers; chromatin pattern coarse } \\
\text { and arranged in clumps; large } \\
\text { eosinophilic nucleolus present }\end{array}$ \\
\hline
\end{tabular}


group are: 1 The presence of significant numbers of normal histiocytes spread diffusely throughout the gland, especially close to the peripheral sinus, or arranged in multiple foci closely simulating the appearance seen in Boeck's sarcoidosis or toxoplasmosis. Small numbers of typical Langhans' type cells were often present (Fig. 11). Caseation necrosis was not found, and all attempts to demonstrate tubercle bacilli have proved negative. 2 Pathognomonic abnormal reticulum cells, which were always multilobed, measuring 20 to $40 \mu$ in size, were present. Some of them had the nuclei arranged in a haphazard manner throughout the cell, while others appeared to have the nuclei arranged in a horse-shoe pattern. In both types, however, the nuclei showed infolding of the membrane, the chromatin pattern was irregular, and the nucleolus was often prominent (Fig. 13).

PATTERN Apart from the generalized increase of density of the reticulin there was no specific pattern such as lobular formation.

RETICULUM CELLS All the cells, as described in the reticular group, were found.

OTHER CELls Plasma cells and eosinophils were prominent in all cases.

On the basis of the criteria used to subdivide the reticular group, ie, more or less than $50 \%$ of the total cell population as normal lymphocytes, the proportion of abnormal reticulum cells and the degree of anaplasia, the patients in the histiocytic group were classified as of the well differentiated type $(7 \%)$ and the pathology is seen in Figs. 9, 10, and 11, and of the poorly differentiated type $(5 \%)$ as seen in Figures 12 and 13.

\section{NODULAR SCLEROSIS GROUP}

Two findings which placed a lymph gland in the nodular sclerosis group were (1) the presence of numbers of fibroblasts producing excessive amounts of collagenous fibrous tissue typically arranged in an encircling manner, and (2) the presence of characteristic large abnormal reticulum cells.

FIBROUS PATTERN A various amount of fibrous tissue was present in the lymph glands of patients with nodular sclerosis, showing separation into irregularly shaped, mostly round, nodules of abnormal lymphoid tissue, surrounded by interconnecting bands of dense fibrous tissue. The nodules varied in size from 0.25 to $3 \mathrm{~mm}$. In some of the glands there were irregular sheets of fibrous tissue in addition to the encircling bands.

In two patients fibrosis in the glands was moderate, appearing as fine strands running throughout, so that a nodular appearance was not obvious. However, in both cases, abnormal reticulum cells, typically seen in nodular sclerosis, were present, and subsequent biopsies, taken during the course of the illness, showed definite nodular patterns.

ABNORMAL RETICULUM CELLS In addition to the varied pattern of abnormal reticulum cells, as described in the reticular group, the following characteristic cells were present. These ranged from 40 to $50 \mu$ in size, with abundant pale-staining cytoplasm. They appeared to produce a space between the cell and the rest of the tissue, and consequently were called 'lacuna' cells by Lukes and Butler (1966) and are shown in Figure 14. Marked infolding of the nucleus was present, giving rise to a varying number of lobules. The nuclear membrane was thin and sharply defined. The chromatin was delicate, and the nucleolus tended to be small and inconspicuous.

OTHER CELLS Eosinophils and plasma cells were a constant feature of the glands, arranged diffusely, or in clumps. In addition, a small number of normal histiocytes were often present. In some cases there were small islands of necrosis, considered to be avascular in origin, and polymorphs were present in the surrounding areas.

By estimating the relative proportion of normal lymphocytes, and abnormal reticulum cells, and the degree of anaplasia of the latter cells, the cases were further subdivided into the well differentiated type (34 cases, $13 \%$ ) as illustrated in Figures 14, 15, and 16. The nodular pattern, as described, was pronounced, but the degree of fibrosis throughout was increased. In general, the cellular composition of the nodule was predominantly lymphocytic and abnormal reticulum cells were scanty. The poorly differentiated type was seen in $12(4 \%)$ cases (Figs. 17 and 18). The nodular pattern was apparent, but the nodules were not as clear cut as in the well differentiated type. Some appeared to be coalescing. Both within and outside the nodules, the number of lymphocytes was considerably reduced. Abnormal reticulum cells were predominant and occasional 'lacuna' cells could be identified. An outstanding feature was the presence of necrosis, sometimes excessive. Surrounding these areas, the abnormal reticulum cells showed a marked degree of anaplasia.

RELATIONSHIP BETWEEN THE HISTOLOGICAL APPEARANCES AND SURVIVAL

The original biopsy material was not available for study in 15 of the 302 patients, but Hodgkin's disease was confirmed by later biopsy, or on necropsy 
findings. In 287 patients, the diagnosis of Hodgkin's disease was established on examination of the lymph gland, on average, within 14 days of presentation of the illness. To determine the incidence of the disease, all patients who presented before January 1967 were accepted in the series.

On histological appearances, each patient was allocated to one of the seven types, the distribution of which is summarized in Table III.

\section{TABLE III}

287 CASES WITH HISTOLOGICALLY PROVEN HODGKIN'S DISEASE ON ORIGINAL BIOPSY DIVIDED INTO THREE GROUPS AND SUBDIVIDED INTO TYPES ${ }^{1}$

\begin{tabular}{|c|c|c|c|}
\hline \multicolumn{2}{|r|}{ Group } & \multicolumn{2}{|c|}{ No. of Patients } \\
\hline 1 & $\begin{array}{l}\text { Reticular } \\
\text { Lymphocytic } \\
\text { Well differentiated } \\
\text { Poorly differentiated }\end{array}$ & $200(70 \%)$ & $\begin{array}{l}26(9 \%) \\
77(27 \%) \\
97(33 \%)\end{array}$ \\
\hline 2 & $\begin{array}{l}\text { Histiocytic } \\
\text { Well differentiated } \\
\text { Poorly differentiated }\end{array}$ & $39(13 \%)$ & $\begin{array}{ll}23 & (8 \%) \\
16 & (6 \%)\end{array}$ \\
\hline 3 & $\begin{array}{l}\text { Fibroblastic } \\
\text { Well differentiated } \\
\text { Poorly differentiated }\end{array}$ & $48(17 \%)$ & $\begin{array}{l}36(13 \%) \\
12(4 \%)\end{array}$ \\
\hline & $\begin{array}{l}\text { No original slides } \\
\text { Total }\end{array}$ & $\begin{array}{r}15 \\
287\end{array}$ & \\
\hline
\end{tabular}

${ }^{1}$ The remaining 15 cases were diagnosed as Hodgkin's disease on a later biopsy or at necropsy.

The reticular group, with $200(70 \%)$ patients, was the largest, followed by the nodular sclerosis group with $48(17 \%)$ patients, and the histiocytic group with $39(13 \%)$ patients.

Subdivision into the various types showed that the poorly differentiated reticular type was predominant, with $97(33 \%)$ patients, followed by the well differentiated reticular type, with $77(27 \%)$ patients, and the well differentiated nodular sclerosis type with $36(13 \%)$ patients.

The lymphocytic reticular type, with $26(9 \%)$ patients, is similar to the incidence of paragranuloma cases in other series (Smetana and Cohen, 1956; Wright, 1956; Lukes and Butler, 1966; Hanson, 1964).

Since 1964, the incidence of nodular sclerosis (Cross, 1968) has increased from 12 to $17 \%$ in the present series. This may be due to the greater number of glands received from females over the past three years.

More recent understanding of the correlation between histology and prognosis is associated with realization of the significance of lymphocytes and fibrous tissue. The relationship of lymphocytic proliferation to a favourable prognosis was first emphasized by Rosenthal (1936), accepted universally in the 'paragranuloma' cases of Jackson and Parker (1944) and in the 'lymphocytic predominance' cases of Lukes and Butler (1966).

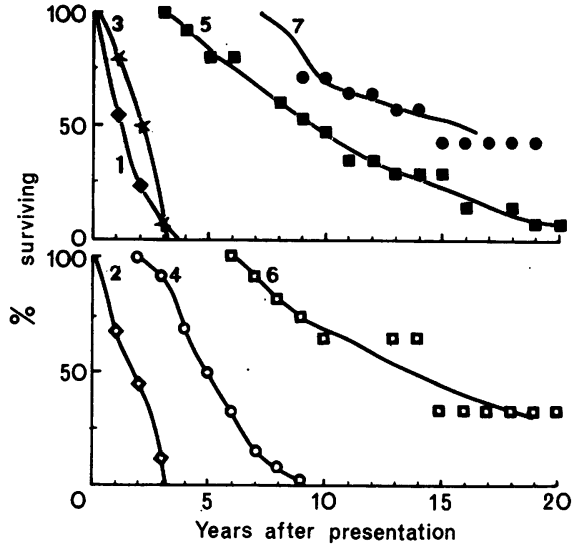

FIG. 19. Cumulative curves for the various types of Hodgkin's disease. 1 Poorly differentiated reticular; 2 poorly differentiated histiocytic; 3 poorly differentiated nodular sclerosis; 4 well differentiated reticular; 5 well differentiated nodular sclerosis; 6 well differentiated histiocytic; 7 lymphocytic reticular.

Fibrosis, in general, has long been recognized as an integral part of the lymph gland appearance in the evolution of Hodgkin's disease (Jackson and Parker, 1944; Smetana and Cohen, 1956) and there seems little doubt that fibrosis, as seen in a specific nodular pattern (Lukes and Butler, 1966; Hanson, 1964; Harrison, 1966; Cross, 1968), plays a significant part in the survival time.

Little attention has been paid to the presence of histiocytes in the lymph glands of patients with Hodgkin's disease, although Harrison (1952), Smetana and Cohen (1956), Wright (1956), and Symmers (1958) made occasional references to sarcoid-like features of Hodgkin's disease. Lukes and Butler (1966) emphasized the association of lymphocytes with reactive histiocytes in certain cases but, as previously indicated, they referred to cells known as normal reticulum cells and not the histiocytes seen in sarcoidosis. Histological appraisal of the glands in this series indicated a relationship between the presence of significant numbers of epithelioid histiocytes and long survival of the patient.

Survival figures were estimated by accepted statistical methods, and only patients who presented before 1 January 1965 were included. The cumulative survival method was used, and results are shown in Figure 19. The curves of lymphocytic reticular, well differentiated histiocytic and well differentiated nodular sclerosis types are similar and distinct from the curve of the well differentiated reticular type; the curves of all three poorly differentiated types show a similar steep gradient. 
TABLE IV

SURVIVAL RATES IN 246 PATIENTS WITH HISTOLOGICALLY PROVEN HODGKIN'S DISEASE DYING OR PRESENTING BEFORE 1 JANUARY 1965

\begin{tabular}{|c|c|c|c|c|c|c|c|c|c|c|}
\hline \multirow[b]{2}{*}{$\begin{array}{l}\text { Type of Hodgkin's } \\
\text { Disease }\end{array}$} & \multirow[b]{2}{*}{$\begin{array}{l}\text { Total } \\
\text { No. }\end{array}$} & \multirow[b]{2}{*}{$\begin{array}{l}\text { No. } \\
\text { Dead }\end{array}$} & \multicolumn{2}{|c|}{ Two-year Survival } & \multicolumn{2}{|c|}{ Five-year Survival } & \multicolumn{2}{|c|}{ 10-year Survival } & \multicolumn{2}{|c|}{ 15-year Survival } \\
\hline & & & $\begin{array}{l}\text { No. } \\
\text { Followed } \\
\text { Up }\end{array}$ & $\begin{array}{l}\text { No. } \\
\text { Surviving } \\
\text { Two Years }\end{array}$ & $\begin{array}{l}\text { No. } \\
\text { Followed } \\
\text { Up }\end{array}$ & $\begin{array}{l}\text { No. } \\
\text { Surviving } \\
\text { Five Years }\end{array}$ & $\begin{array}{l}\text { No. } \\
\text { Followed } \\
\text { Up }\end{array}$ & $\begin{array}{l}\text { No. } \\
\text { Surviving } \\
10 \text { Years }\end{array}$ & $\begin{array}{l}\text { No. } \\
\text { Followed } \\
\text { Up }\end{array}$ & $\begin{array}{l}\text { No. } \\
\text { Surviving } \\
15 \text { Years }\end{array}$ \\
\hline \multicolumn{11}{|l|}{ Reticular Group } \\
\hline Lymphocytic & 22 & 8 & 22 & $22(100 \%)$ & 21 & $21(100 \%)$ & 15 & $11(73 \%)$ & 10 & $3(30 \%)$ \\
\hline Well differentiated & 71 & 60 & 71 & $70(98 \%)$ & 62 & $28(45 \%)$ & 47 & Nil & 38 & Nil \\
\hline Poorly differentiated & 88 & 88 & 88 & $18(20 \%)$ & 80 & Nil & 64 & Nil & 53 & Nil \\
\hline \multicolumn{11}{|l|}{ Histiocytic Group } \\
\hline Well differentiated & 16 & 6 & 16 & $16(100 \%)$ & 15 & $15(100 \%)$ & 12 & $7(58 \%)$ & 4 & $1(25 \%)$ \\
\hline Poorly differentiated & 10 & 10 & 10 & $6(60 \%)$ & 8 & Nil & 6 & Nil & 2 & $\mathrm{Nil}$ \\
\hline \multicolumn{11}{|l|}{ Nodular Sclerosis Group } \\
\hline Well differentiated & 28 & 18 & 28 & $28(100 \%)$ & 23 & $20(87 \%)$ & 16 & $8(50 \%)$ & 12 & $4(33 \%)$ \\
\hline Poorly differentiated & 11 & 11 & 11 & $6(54 \%)$ & 8 & Nil & 6 & Nil & 2 & Nil \\
\hline Total & 246 & 201 & 246 & $166(67 \%)$ & 217 & $84(38 \%)$ & 166 & $26(16 \%)$ & 121 & $8(7 \%)$ \\
\hline
\end{tabular}

The two-, five-, 10-, and 15-year survival rates (Table IV) show that within each group the survival rates for the well differentiated types are significantly higher than the survival rates for the poorly differentiated types.

The two-year survival rate for the poorly differentiated reticular type is significantly lower (at the $5 \%$ confidence level) than the survival rate for the poorly differentiated histiocytic and nodular sclerosis types combined.

The five-year survival rate for the well differentiated reticular type is significantly lower than the survival rates for the well differentiated histiocytic and nodular sclerosis types.

There is no significant difference in the survival rate between the lymphocytic reticular type and the well differentiated histiocytic type and the well differentiated nodular sclerosis type.

In the lymphocytic reticular type the two-year and five-year survival rate of $100 \%$, the 10 -year rate of $73 \%$, and the 15 -year rate of $30 \%$ support the view that there is a good prognosis in cases which show large numbers of lymphocytes. This is also demonstrated in the $100 \%$ two-year survival rate of the well differentiated types, compared with the highest $(60 \%)$ two-year survival rate in the poorly differentiated types.

There is a significant relationship between survival time and the presence of histiocytes and fibrous tissue, and, although lymphocytes are not so numerous in the well differentiated histiocytic and nodular sclerosis types, as in the lymphocytic reticular type, all three types show a similar excellent prognosis in the five-, 10- and 15-year survival rate. The prognosis in all three poorly differentiated types is poor, and, although the numbers of poorly differentiated histiocytic and nodular sclerosis types are small, there is some suggestion that they have a slightly better prognosis than the poorly differentiated reticular type.
The proposed histological classification divides Hodgkin's disease into more homogeneous groups from the point of view of prognosis as follows:

Group

\begin{tabular}{lll}
\hline Reticular & Histiocytic & Nodular Sclerosis \\
\hline $\begin{array}{l}\text { Lymphocytic } \\
\text { (Paragranuloma) }\end{array}$ & & \\
$\begin{array}{l}\text { Well differentiated } \\
\text { Poorly differentiated }\end{array}$ & $\begin{array}{l}\text { Well differentiated } \\
\text { Poorly differentiated }\end{array}$ & $\begin{array}{l}\text { Well differentiated } \\
\text { Poorly differentiated }\end{array}$
\end{tabular}

Multiple biopsies of the same patient, taken at various intervals during the course of the illness, indicated the tendency to maintain group specificity. In each case there was a gradual depletion of the numbers of lymphocytes and increase in abnormal reticulum cells, and the latter, in time, showed a more anaplastic appearance. The progress, therefore, was always toward the poorly differentiated in each group and never the reverse.

From these findings it is considered that histological assessment of the lymph gland in Hodgkin's disease can make a valuable contribution in assessing prognosis. Further improvement can be achieved by a combination of histological and clinical findings; this will be the subject of a future communication.

I wish to express my thanks to Professor C. V. Harrison, Air Vice-Marshal Sir Peter Dixon, Air Vice-Marshal W. P. Stamm, Wing Commander P. J. Stevens, and Squadron Leader A. W. McCracken for their helpful advice and criticism. I am grateful to Miss D. Lindsay, Flight Sergeant P. Mulhall, and Mrs Pearce for the clerical and administrative help, and to the DirectorGeneral of Medical Services, Royal Air Force, for permission to publish.

\section{REFERENCES}

Aisenberg, A. C. (1964). New Engl. J. Med., 270, 508, 565 and 617. Cross, R. M. (1968). J. clin. Path., 21, 303.

Dawson, P. J., and Harrison, C. V. (1961). Ibid., 14, 219. 
Franssila, K. O., Kalima, T. V., and Voutilainen, A. (1967). Cancer (Philad.), 20, 1594.

Gall, E. A., and Mallory, T. B. (1942). Amer. J. Path., 18, 381.

Greenfield, W. S. (1878). Trans. path. Soc. Lond., 29, 272.

Hanson, T. A. S. (1964). Cancer (Philad.), 17, 1595.

Harrison, C. V. (1952). J. Path. Bact., 64, 513.

(1966). Recent Advances in Pathology, 8th ed. Churchill, London.

Hilton, G., and Sutton, P. M. (1962). Lancet, 1, 283.

Hodgkin, T. (1832). Med. chir. Trans., 17, 68.

Jackson, H., Jr, and Parker, F., Jr (1944). New Engl. J. Med., 230,$1 ; 231,35$, and 639 .

- (1947). Hodgkin's Disease and Allied Disorders. Oxford University Press, New York.

Karnofsky, D. A. (1966). Cancer Res., 26, 1090.

Letterer, E. (1924). Frankfurt. Z. Path., 30, 377.

Lukes, R. J. (1963). Amer. J. Roentgenol., $90,944$.

- , and Butler, J. J. (1966). Cancer Res., 26, 1063.

Lumb, G. and Newton, K. A. (1957). Cancer (Philad.), 10, 976.
Marshall, A. H. E. (1956). In An outline of the Cytology and Pathology of Reticular Tissue, p. 20. Oliver and Boyd, Edinburgh.Maximow, A. A. (1932). In Special Cytology, Vol. 2, p. 610. Edited by E. V. Cowdry. Hoeber, New York.

Peters, M. V. and Middlemiss, K. C. H. (1958). Amer.J. Roentgenol. 79, 119.

Pullinger, B. D. (1932). In Rose Research on Lymphadenoma, p. 117. By T. Horder et al. John Wright, Bristol.

Reed, D. M. (1902). Johns Hopk. Hosp. Rep., 10, 133

Robb-Smith, A. H. T. (1938). J. Path. Bact., 47, 457.

Rosenthal, S. R. (1936). Arch. Path, 21, 628.

Smetana, H. F., and Cohen, B. M. (1956). Blood, 11, 211.

Sternberg, C. (1898). Z. Heilk., 19, 21

Symmers, W. St. C. (1958). In Cancer, Vol. 2. p. 448. Edited by R. W. Raven. Butterworth, London.

Wilks, S. (1865). Guys Hosp. Rep., 11, 56.

Wright, C. J. E. (1956). Cancer (Philad.), 9, 773.

\section{The January 1969 Issue}

\section{THE JANUARY 1969 ISSUE CONTAINS THE FOLLOWING PAPERS}

Automation in the laboratory M. G. NELSON

An evaluation of the AutoAnalyzer SMA-4 T. R. J. LAPPIN, A. LAMONT, and M. G. NELSON

A report on experience with an automatic blood counting machine A. E. GREEN, V. L. MIDDLETON, K. G. PRENTIS, and A. G. SIGNY

Comparison of the effect of heparin and citrate on platelet aggregation J. R. O'BRIEN, S. M. SHOOBRIDGE, and W. J. FINCH

Fibrinolytic response to moderate exercise in young male diabetics and non-diabetics J. D. CASH and R. C. MCGILL

Transient appearance of fibrinolytic activity at the epithelium of the rat uterus KONSTANTINOS TYMPANIDIS and TAGE ASTRUP

Examination by electron microscopy of the San Carlos viruses isolated from children with infectious hepatitis A. J. ZUCKERMAN, R. G. BIRD, LORNA J. DUNKLEY, and G. J. LOVE

Electron microscopic observations on the virus particles in Herpes simplex encephalitis s. ROY and L. WOLMAN

Acute hepatitis due to Herpes simplex virus in an adult T. H. FLEWETT, R. G. F. PARKER, and W. M. PHILIP
Urinary excretion of glycosaminoglycans in the various forms of gargoylism G. MANLEY and U. WILLIAMS

Serum globulins and infections in mongolism GRIFFITHS, P. E. SYLVESTER, and E. MARY BAYLIS

Comparative study of immunological tests for pregnancy diagnosis JOYCE L. BELL

Aberrant glandular polypi of the uterine cervix associated with contraceptive pills: Pathology and pathogenesis A. D. T. GOVAN, W. P. BLACK, and JESSIE L. SHARP

Comparative antibacterial activity of hexachlorophane $\frac{0}{3}$ in different formulations used for skin disinfection? J. W. GIBSON

Use of tissues embedded in epoxy resin for routine을 histological examination of renal biopsies $w$. NOEL EASTHAM and W. B. ESSEX

Technical methods

Enumeration of platelets using a model B counter ELIZABETH E. MAYNE and JOHN M. CARVILLE

Separation of haemoglobins on cellulose acetate J. KOHN

Apparatus for shell freezing liquids in the standardo blood transfusion bottles G. W. R. DIKE, F. E. BEW, and G. G. HOPWOOD

Letters to the Editor

Book reviews

Copies are still available and may be obtained from the PUBLISHING MANAGER, BRITISH MEDICAL ASSOCIATION, TAVISTOCK SQUARE, W.C.1, price $21 \mathrm{~s}$. 